\title{
القصة والسيناريو والهوار في النص الشعري العربي المعاصر
}

Story, script, and dialogue in the contemporary Arabic poetic text

\author{
slel \\ د.عبد الله رمخسان خلف مرهيى \\ Dr. Abdullah Ramadan Khalaf Morsi \\ أستاذ الأدب والنقد المشارك - كلية اللغات - جامعة المدينة العالمية - ماليزيا
}

Doi: 10.21608/mdad.2021.184421

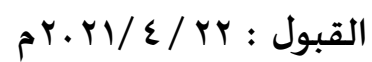

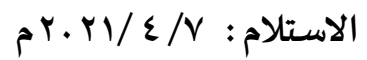

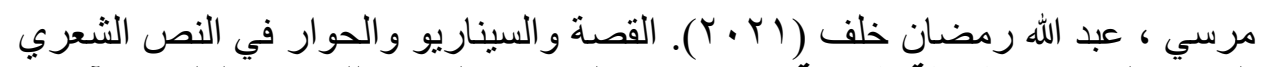

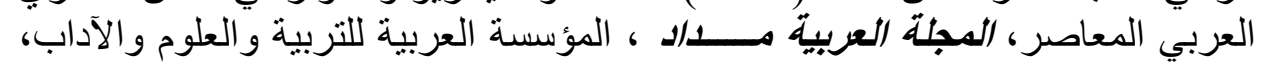

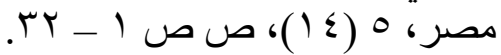




\section{القصة والسيناريو والحوار في النص الشعري العربي المعاصر}

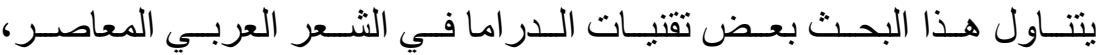

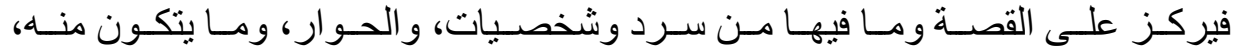

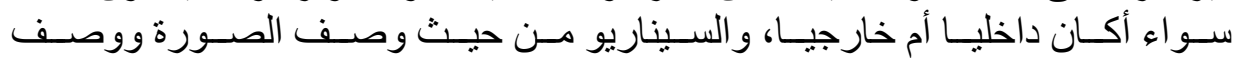

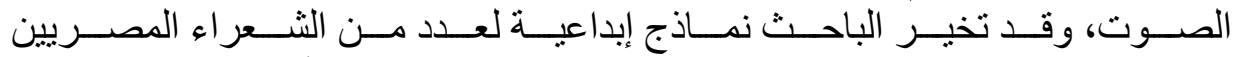

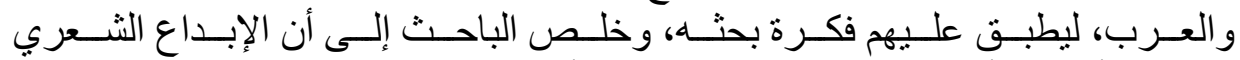

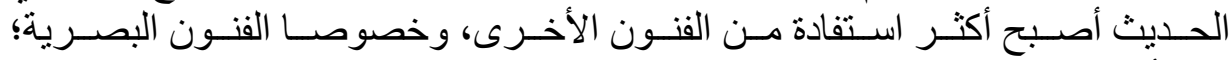

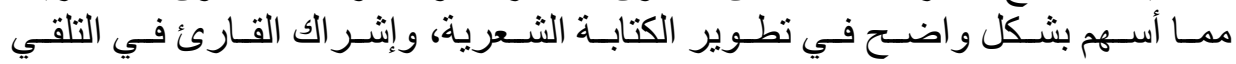

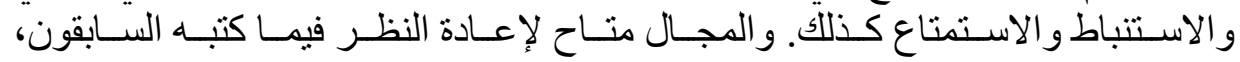
و الانطلاق منه للإضافة إلى الإنى منجز هم.

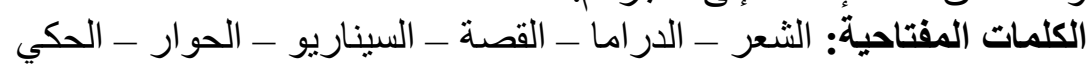

\section{ABSTRACT:}

This research deals with some techniques of drama in contemporary Arabic poetry, focusing on the story and its narration and characters, dialogue, and what it consists of, whether internal or external, and the scenario in terms of describing the image and describing the sound. The researcher has chosen creative models for a number of Egyptian and Arab poets, to apply to them the idea of his research, and the researcher concluded that modern poetic creativity has become more benefit from other arts, especially visual arts; Which clearly contributed to the development of poetic writing, and the reader's involvement in receiving, deduction and enjoyment as well. And the space is available for researchers to write more and more about these issues and touch them with many of the contemporary Arab poets.

Keywords: poetry - drama - story - script - dialogue storytelling 


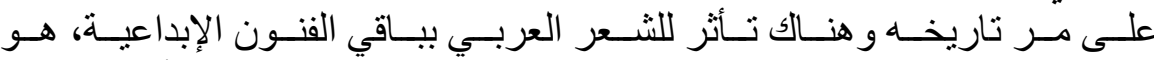

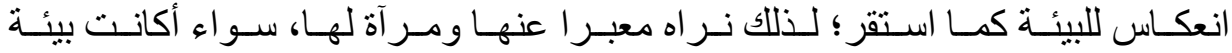

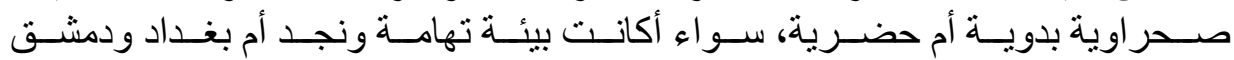

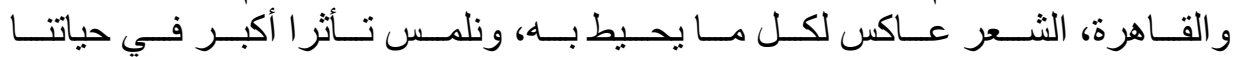

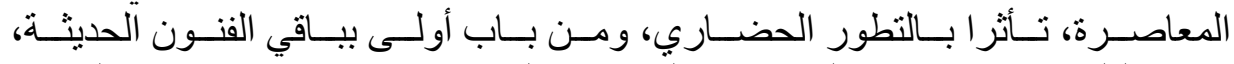

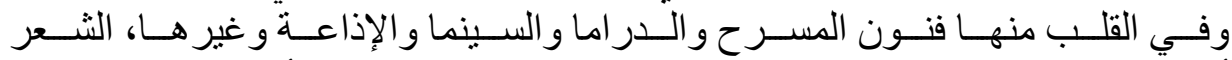

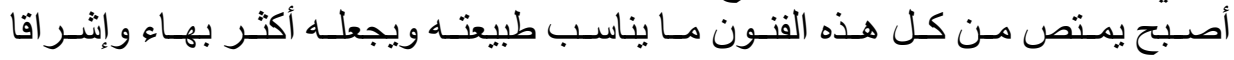

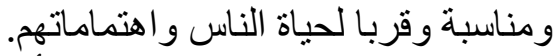

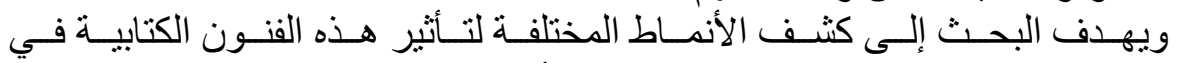

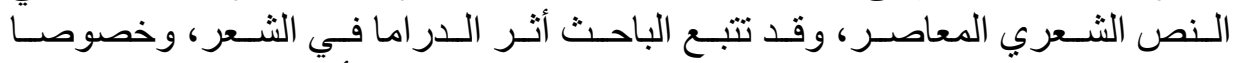

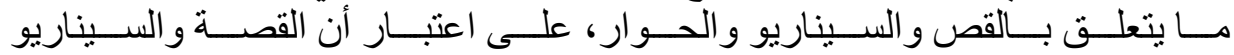

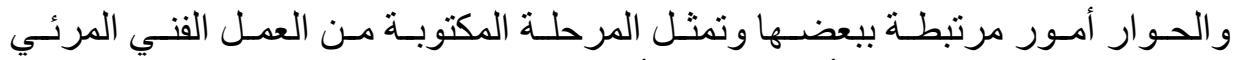

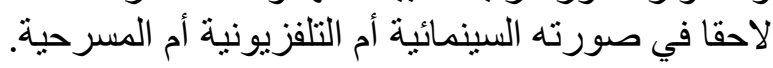

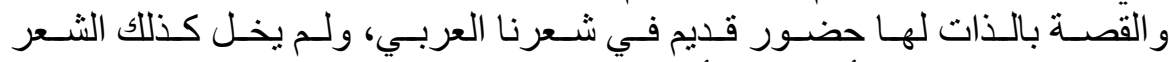

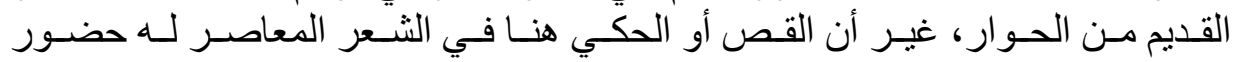

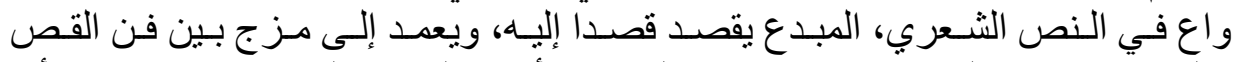

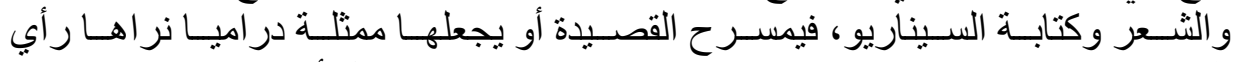

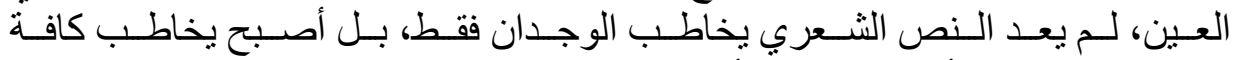

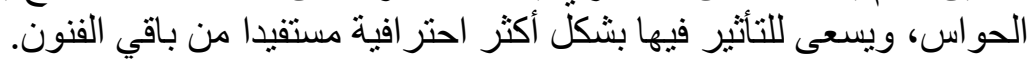

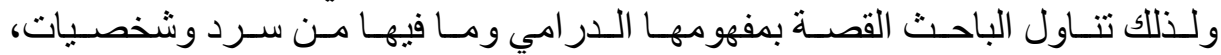

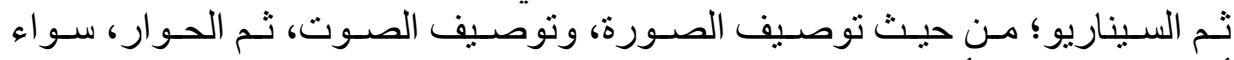
أكان حوار الداخليا أم خارجيا.

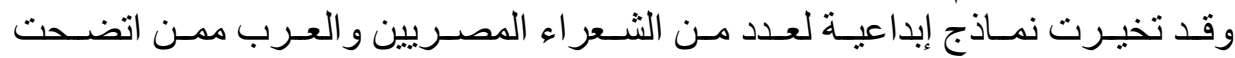

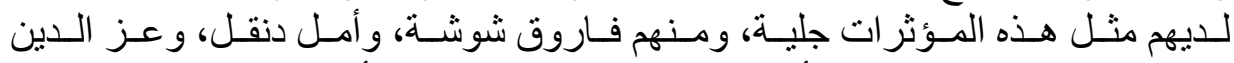

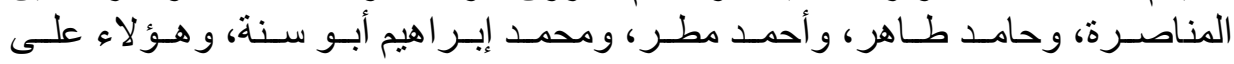

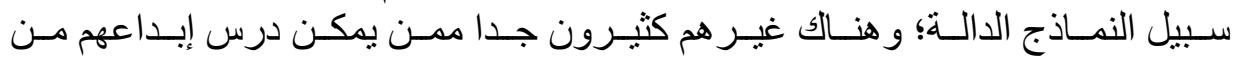
هذه الز اوية.

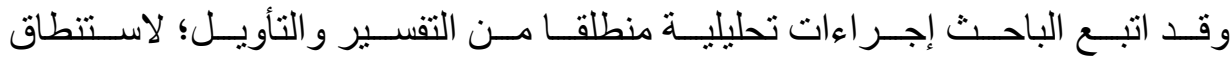
النصوص وتلنمس هذه الآثار فيها. وبعد، نسأل الله أن يكون عملنا نافعا للبحث العلمي و الباحثين. 


\section{r- القصة وتجلياتها في النص الثعري المعاصر:}

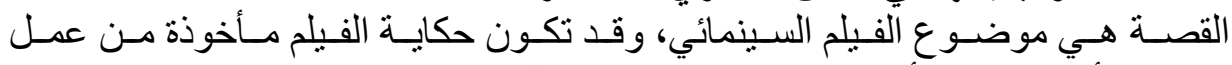

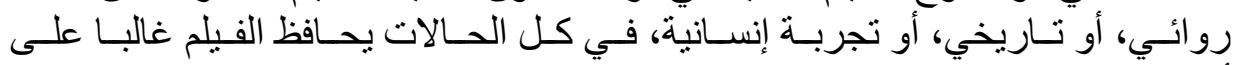

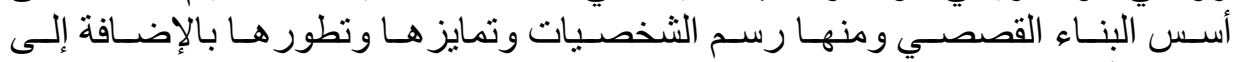
تطور الأحداث، وتصاعدها.

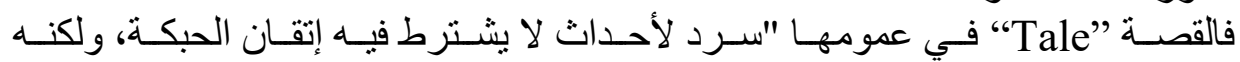

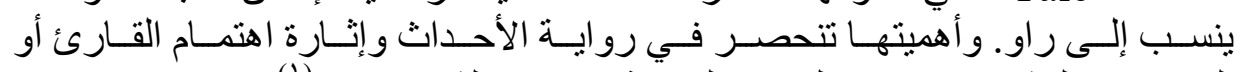

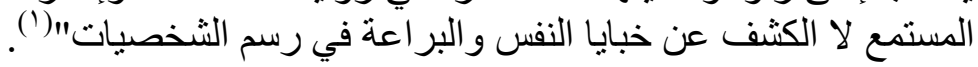
السرد:

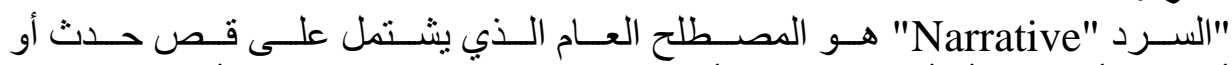

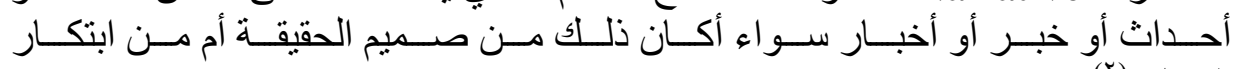

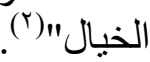

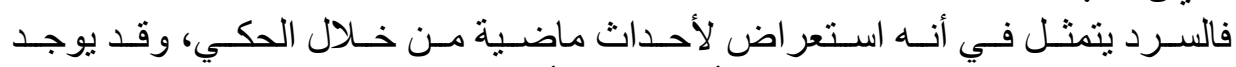

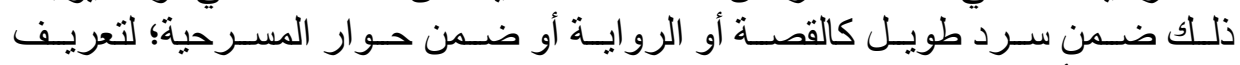

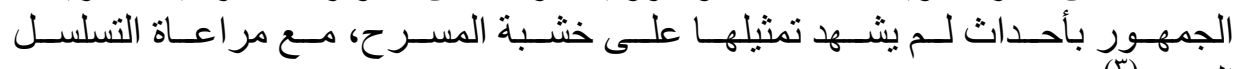
الزمني (r) (الجمه

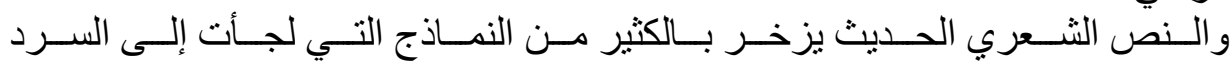

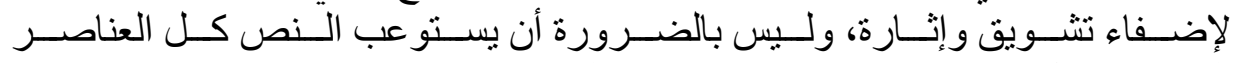

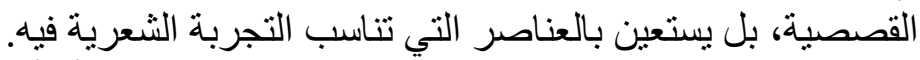

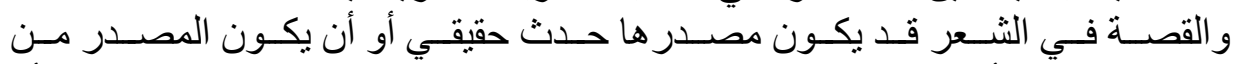

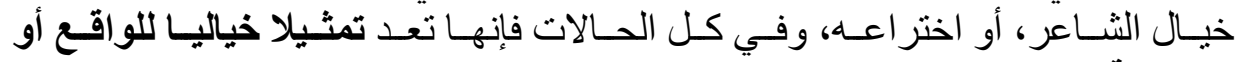

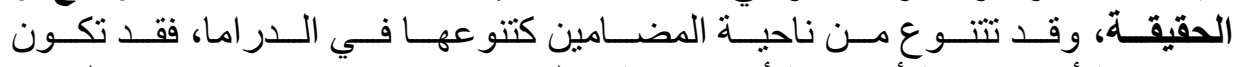

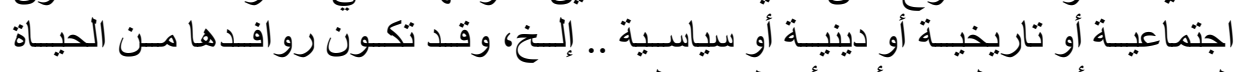

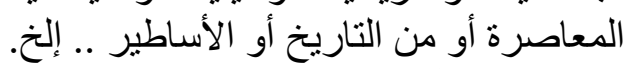

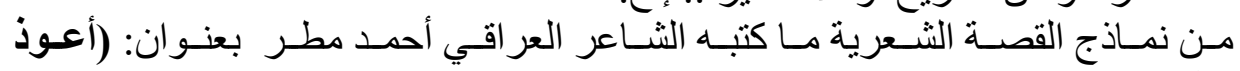
بالله): شيطان شعري زارني

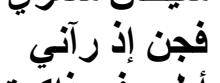
أطبع في ذاكرتي ذاكرة النسيان

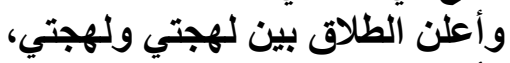

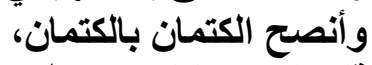
قلت له: "كفاك يان شيطاني، بالكان، 
فإن ما لقيته كفاني، إياك أن تحفر لي مقيرني، بمعول الأوزان

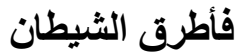
ثم ارمانعت في صدره ومرارة الإيمان وقبل أن يوحي لي قصيدني،

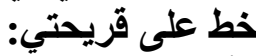

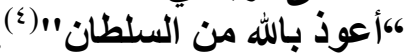

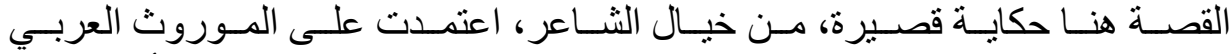

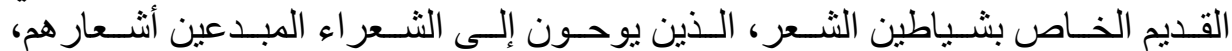

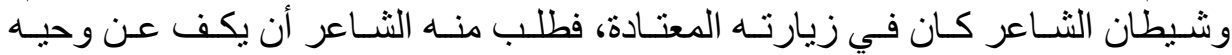

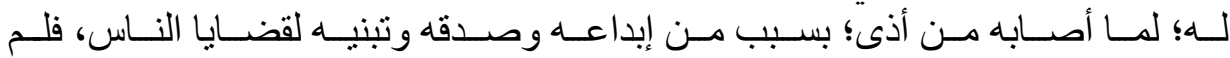

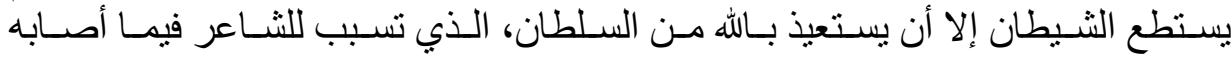

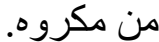

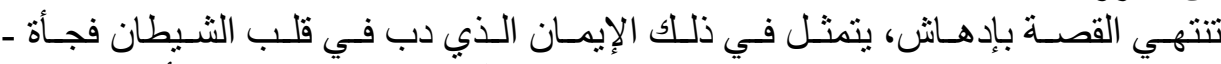

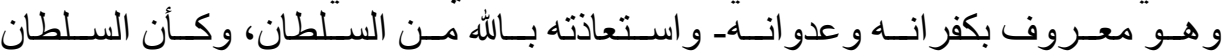

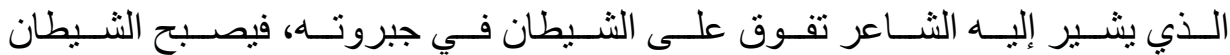
بجواره مؤمنا، رقيق القلب، يتضامن مع الثئ الإنسان.

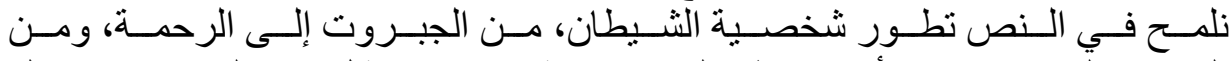

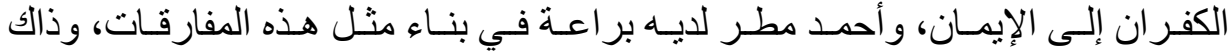

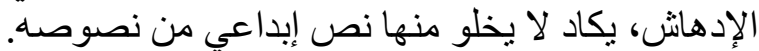

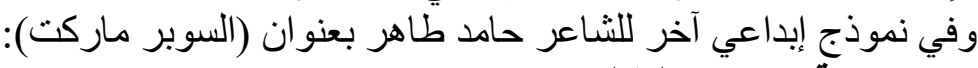
كانت زوجة (إبراهيم البقال)

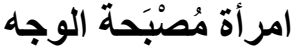

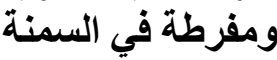
لكني لم أعرفها إلا طيبة القلب،

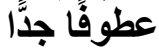
كانت تعرف أطفال الثارع فردًا فردًا وتنادينا أحيانًا فتلاطفنا..

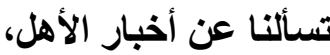
وتعطينا الحلوى 


$$
\begin{aligned}
& \text { في بعض الأحيان } \\
& \text { كاتت تتركنا في الأدان، }
\end{aligned}
$$

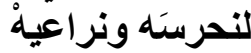

$$
\begin{aligned}
& \text { كنا نتبارى أن نرضيها }
\end{aligned}
$$

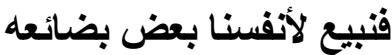

$$
\begin{aligned}
& \text { حتى نعطيها الأثمان }
\end{aligned}
$$

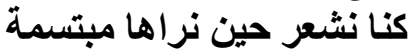

$$
\begin{aligned}
& \text { أن الكون أمان! }
\end{aligned}
$$

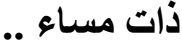

$$
\begin{aligned}
& \text { أغلقت الاكان وكاتت تبكي } \\
& \text { دمع صاف، ونشيج عات متكتم }
\end{aligned}
$$

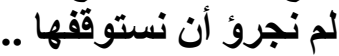

$$
\begin{aligned}
& \text { كنا أصغر من أن نسأل سيدة، } \\
& \text { عن سر بكاها } \\
& \text { لكنا كنا نتألم!! }
\end{aligned}
$$

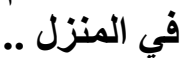

$$
\begin{aligned}
& \text { قالت أمي } \\
& \text { ـ طلقها الملعون، }
\end{aligned}
$$

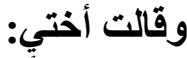

$$
\begin{aligned}
& \text { - زوجته الأخرى أرفع: } \\
& \text { انفجروا ضحكًا } \\
& \text { لم أتمالك نفسي، فصرخت فهم ارفم } \\
& \text { ـ ق قسما هي أروع }
\end{aligned}
$$

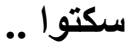

$$
\begin{aligned}
& \text { حين التفتوا نحوي . . } \\
& \text { وجدوني أبكي! } \\
& \text { ** } \\
& \text { مضث الأعوام. } \\
& \text { وحين رجعت لشار عنا } \\
& \text { أدهشني أن أجد الدكان }
\end{aligned}
$$

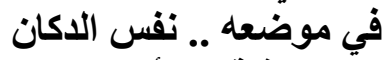

$$
\begin{aligned}
& \text { لكن اللافتة امتلأت بالعنوان }
\end{aligned}
$$




\section{"إبرا هيمكو .. سوبرماركت"(0).}

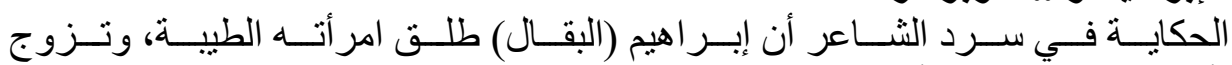

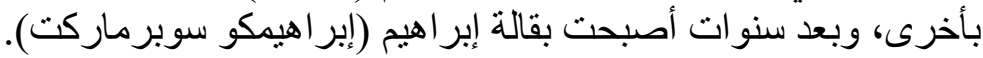

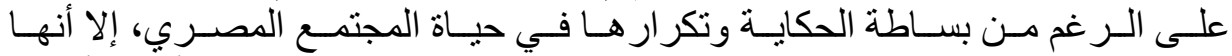

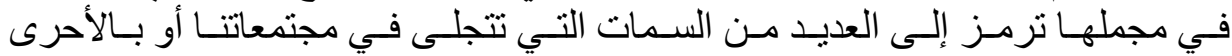

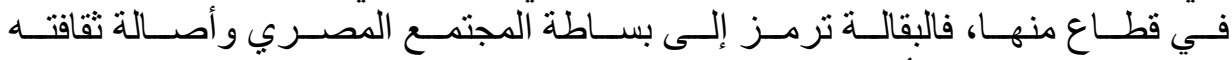

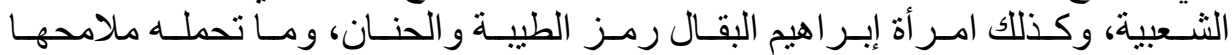

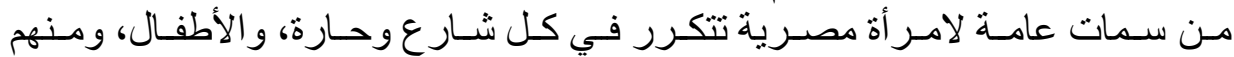

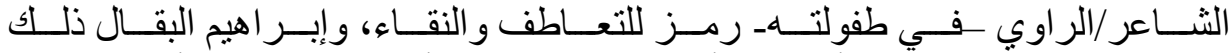

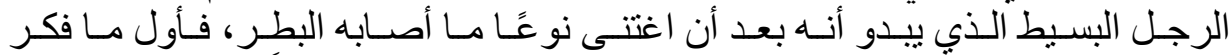

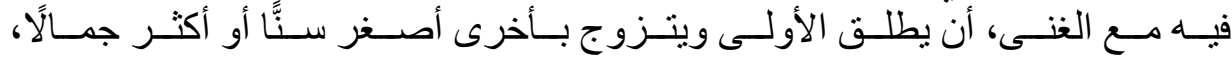

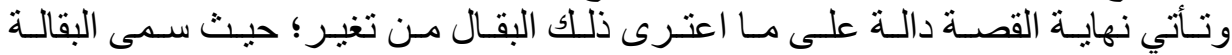

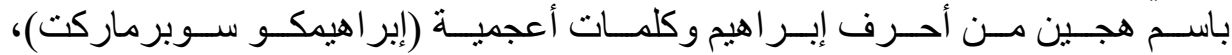

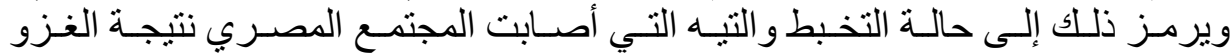
التقافي الغربي الذي لم يترك صغيرة ولا لا كبيرة في حياة الدصريين إلا اقتحمها.

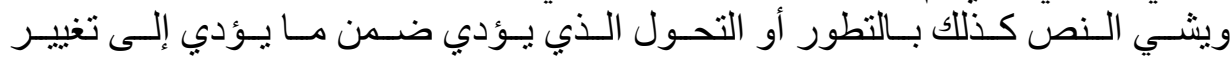

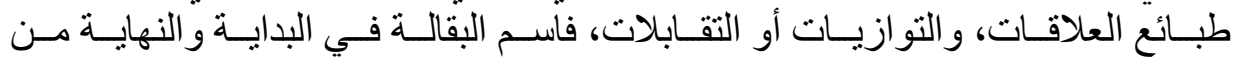

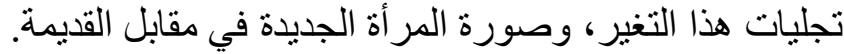

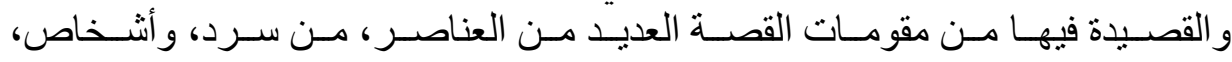
ووصف، وتطور للحدث، وحوار.

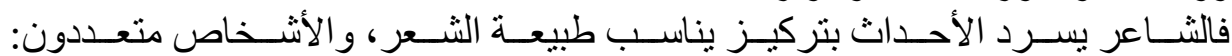

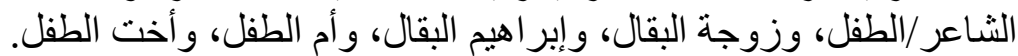

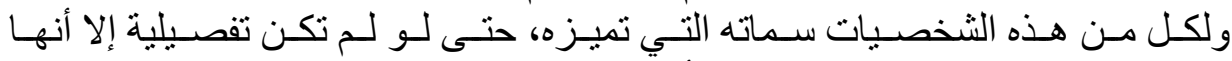

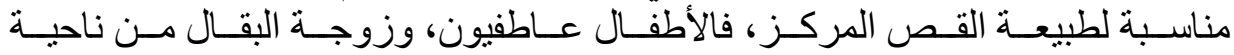

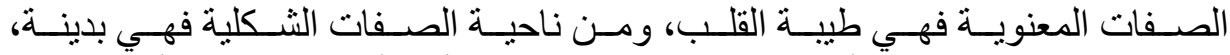

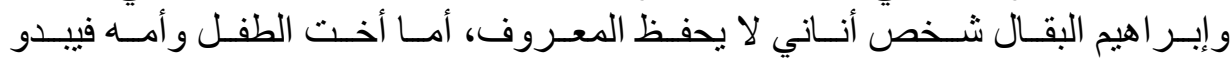

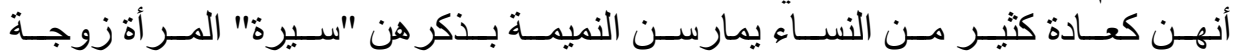

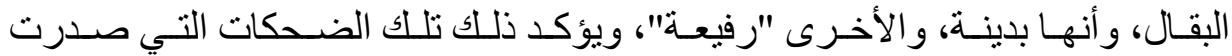

منهن.

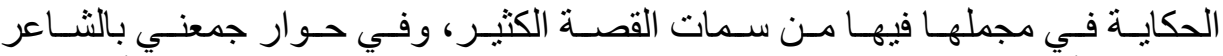

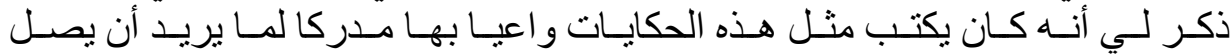
لمتلقيه من قيم فنية وثقافية. 


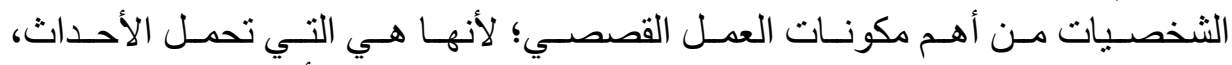

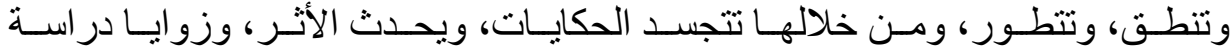

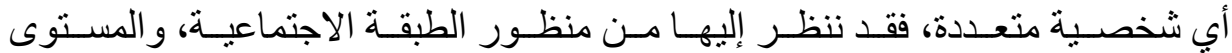

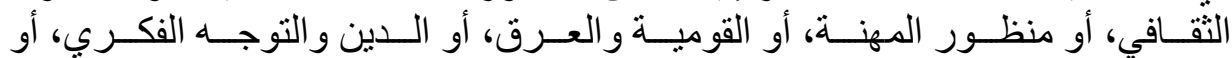
السمات الخاصة المعنو مأفية أو الثكلية .. إلخ.

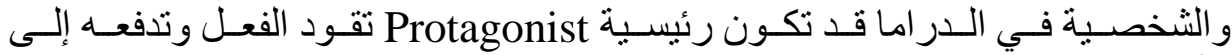

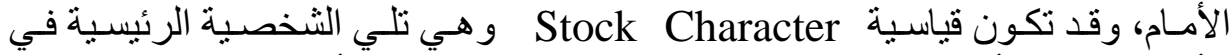

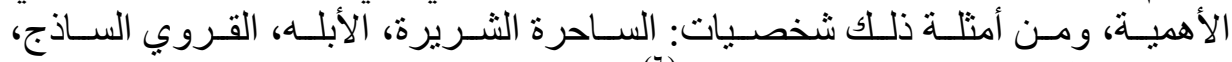

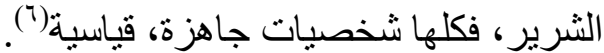

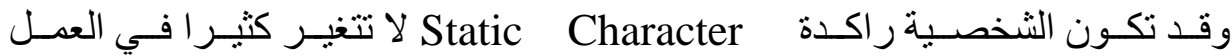

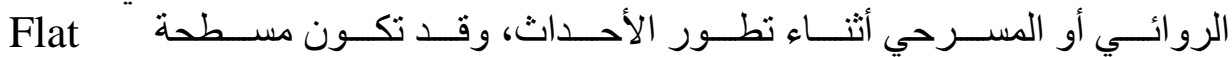
Character

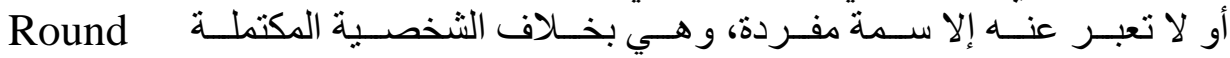
Character

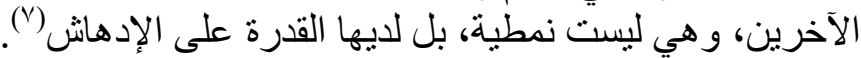

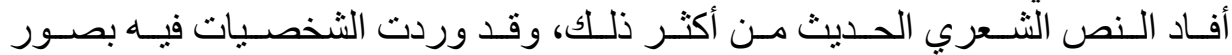

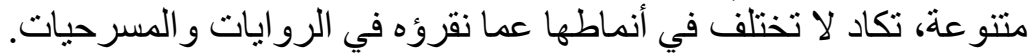

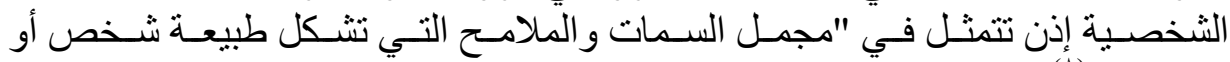
كائن حي" (^)

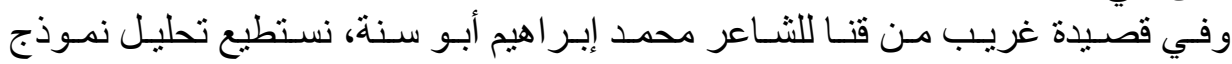

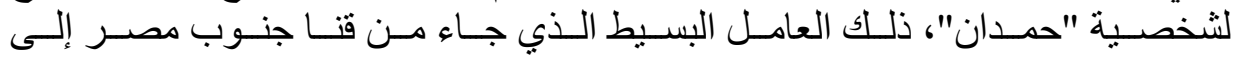

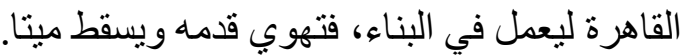

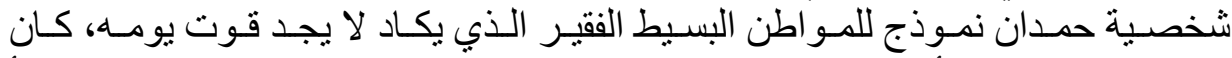

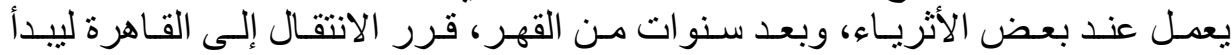

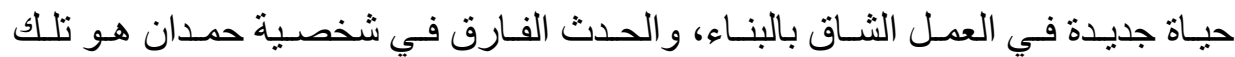

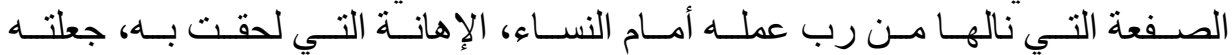

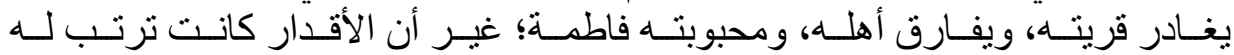

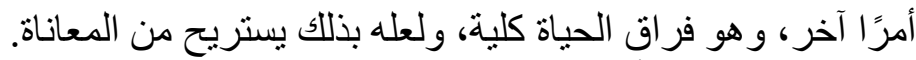
يقول محمد إبر اهيم أبو سنة:

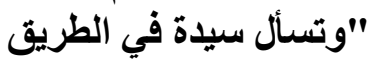
ومن ذا القتيل 


$$
\begin{aligned}
& \text { ويهمس صوت جليل } \\
& \text { "غريب أتى من قنا" ويل } \\
& \text { ويعمل بين رجال البناء } \\
& \text { هوت رجله ثم زلت وحم القضاء }
\end{aligned}
$$

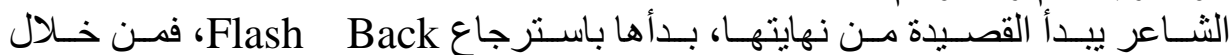

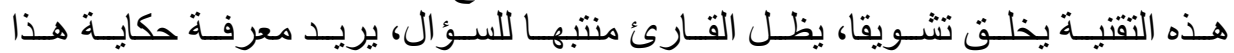

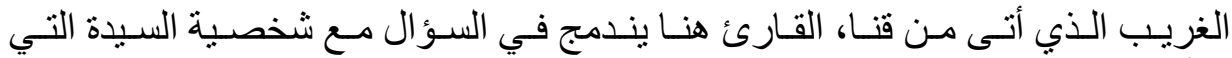
تسأل: ومن ذا القتيل؟ وبعد هذا المشهد يبدأ الثاعر السرد والتصو التصوير البار ع لحكاية حمدان: وعند انكسار المدار وفي وانثى اللثمال القطار المدار

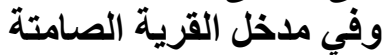
تصاعد بعض الغبار وعينان فوق طريق الحقول تفتش بين جباه الرجال وحمدان ما كان خلف الجمال فبالأمس عند ان مان خلفاء النهار الجمار بكى وانثى للثمال القطار $* * *$

وحمدان يمضي لأرض الثمال ككل رجال الصعيد ككل بناة المدن ومن دمعة في الجفون رأى أمه و والعيال وشيخا ومسبحة في العنق والقيال

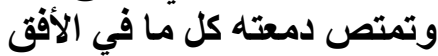
وحمدان مذ كان طقلا يسوق الجمال ويعمل عند رجال مذان يرون الحياة لمن يقدرون ومن يملكون وأن السيادة للأقوياء

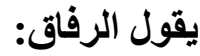


وحمدان كان رخيا كريح الشمال وكان صبيا يعلق فوق الجبين تميمة خوف من الحاسدين

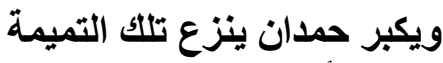
ويؤمن أن الحياة لمن يعملون وعند الغدير وفاطمة في النساء النياء

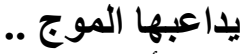
. تملأ بالماء جوف الإنـاء وحمدان يسقي الجمال

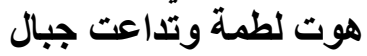
على خد حمدان . .

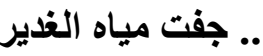
وسيد حمدان يظهر قوته للنساء وغاصت بحمدان في الطين أقدامهـ فيقسم ألا يبيت وعند المساء يقول لفاطمة عن هواه "كلاما جميلا ككل كلام هول يقال قبيل الفراق

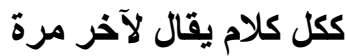
ويرتف حمدان "مرة لاخت هرة حياة تنال بلطم الخدود سأرحل نحو الشمال لأبني مع الراحلين المدن المديال أدبر أمر الحياة العسير المين المنال و آتي لنرحل زوجين التياة يالعير فاطمة

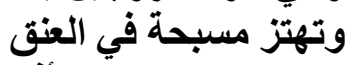
ويهرب من مقلتيه الأفق مئق ويرسو القطار ويكدح حمدان يشقي طوار ال النهار وبالليل غنى لفاطمة عن حريق الضلوع النوار 


$$
\begin{aligned}
& \text { وميل القلوع } \\
& \text { مع الريح تمضي لغير المراد } \\
& \text { ويصعد فوق البناء } \\
& \text { "خرافة رمل وماء ولئاء } \\
& \text { ويهوي وتسأل سيدة في الطريق } \\
& \text { "ومن ذا القتيل } \\
& \text { ويهمس صوت جليل } \\
& \text { "غريب أتى من قنا") (9) }
\end{aligned}
$$

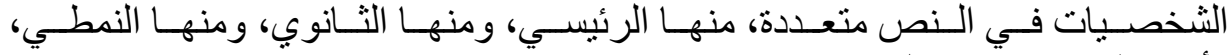

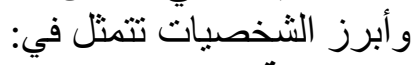

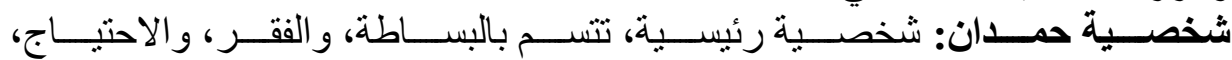

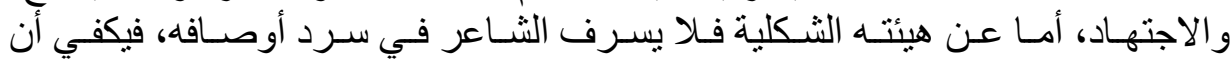

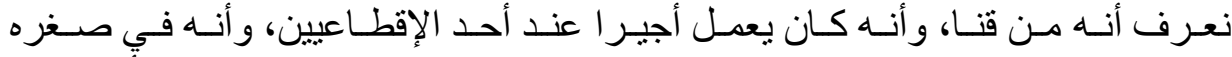

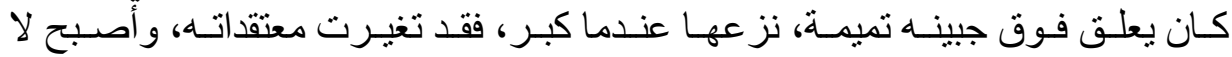

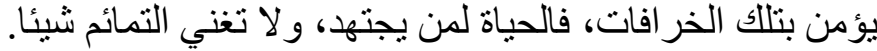

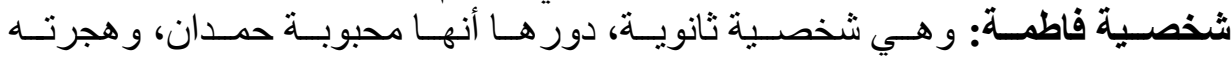

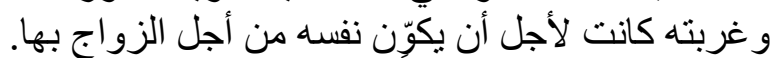

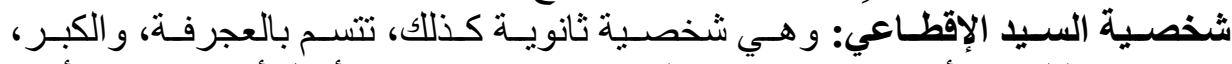
ومـا يتبع ذلك مـ أمراض نفسية، جعلته يصفع حمدان مـن أجل أن يثبت قوة أمسام

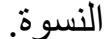

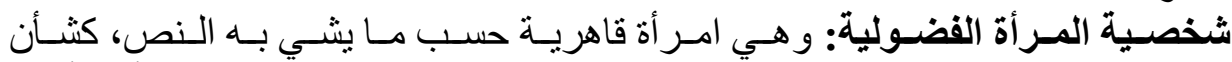

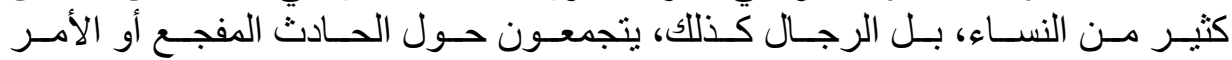

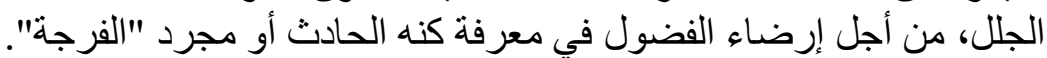
الراوي: وهو هنا الثناعر الذي يسرد الأحداث، وتثنابكها وتطور هـا.

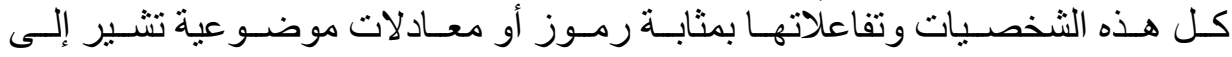

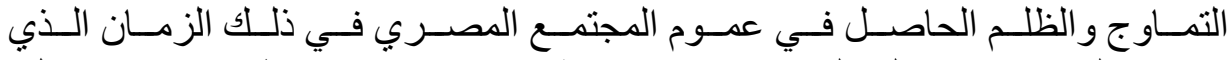

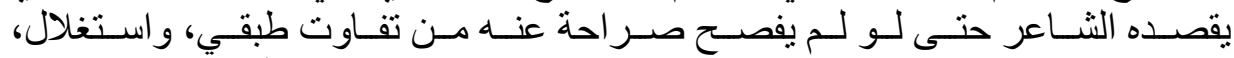

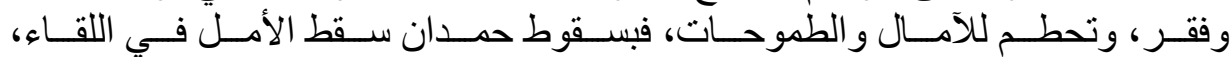
و هوى الطموح في الارتقاء، فهو مجرد قتتيل غريب من فنا.

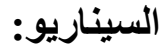

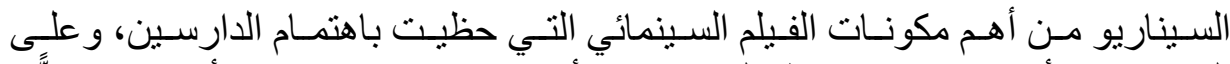

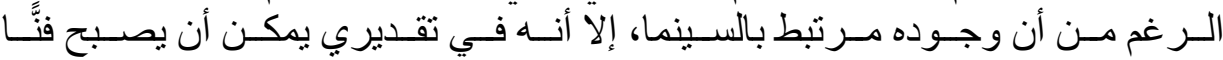




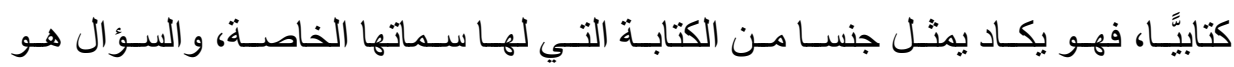

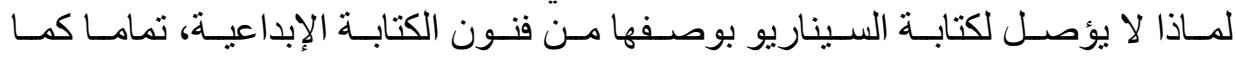

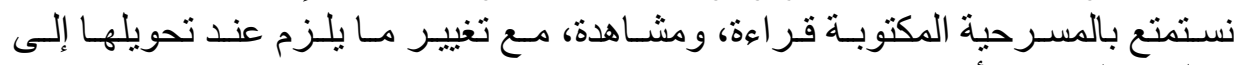

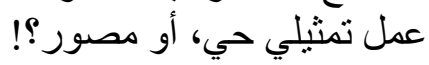

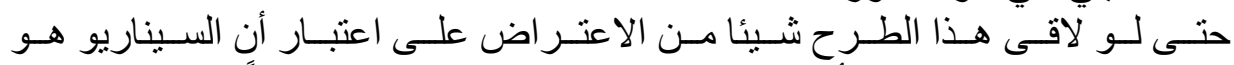

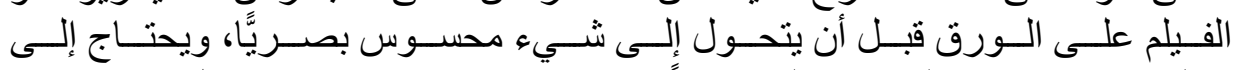

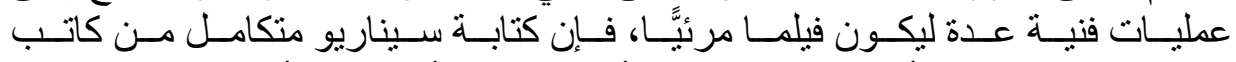

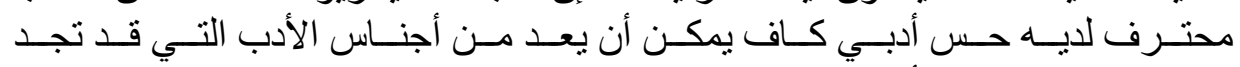

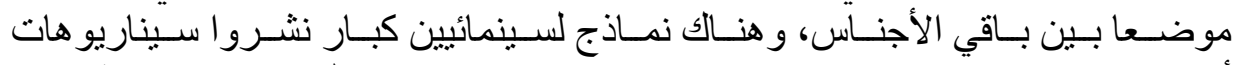

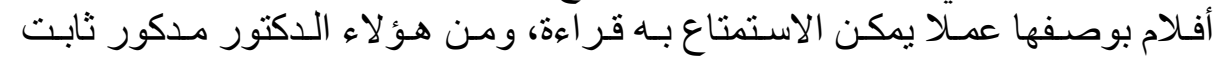

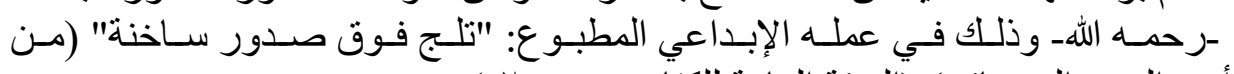

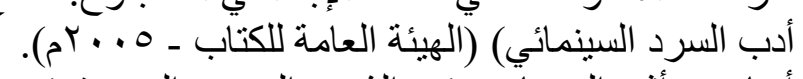

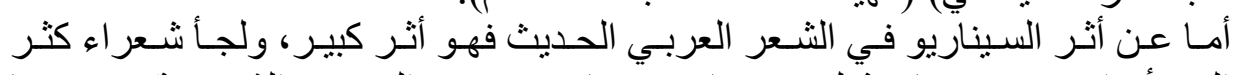

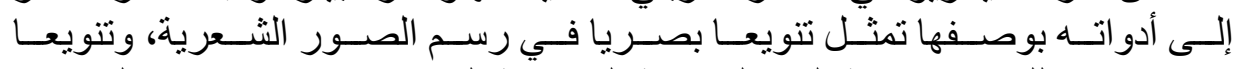

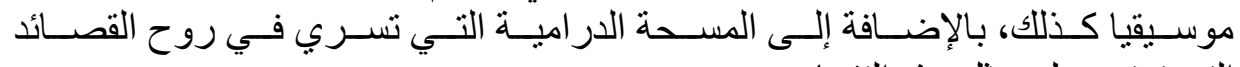
التي تعتمد على مثل هذه التقنيات.

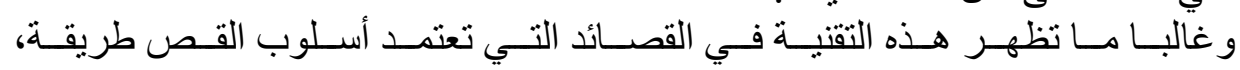
والحوار منهجًا.

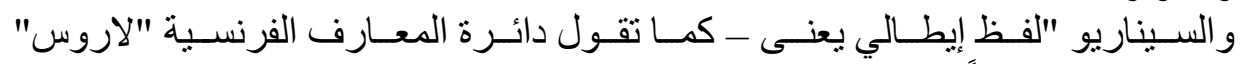

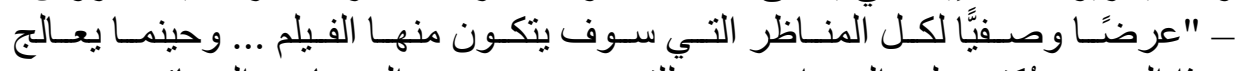

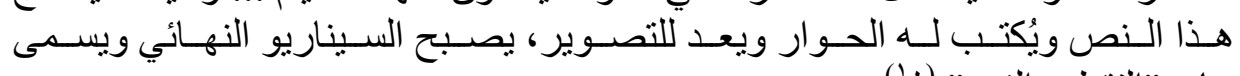

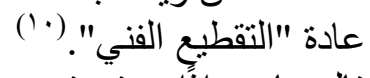

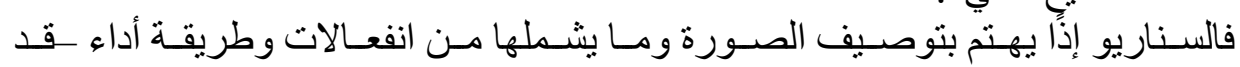

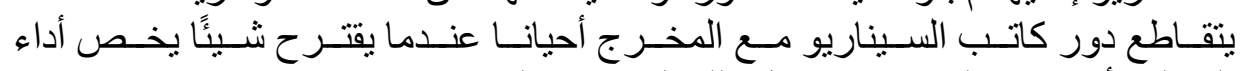

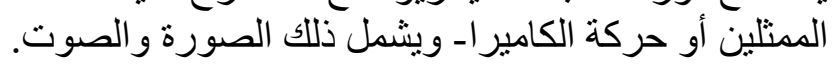
توصيف الصورة

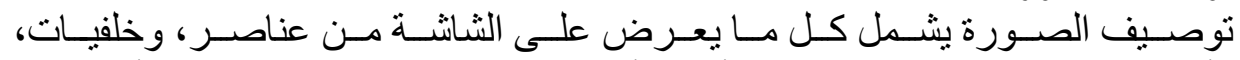

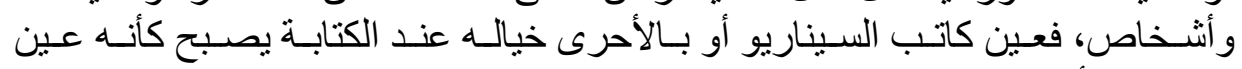

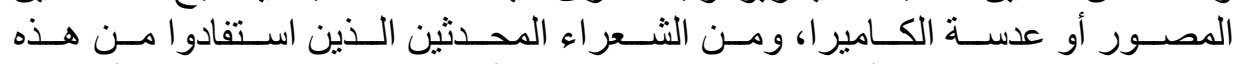

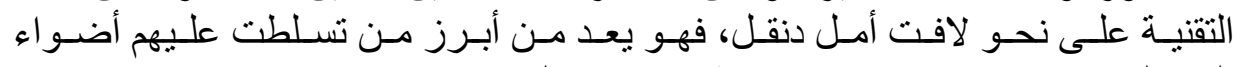

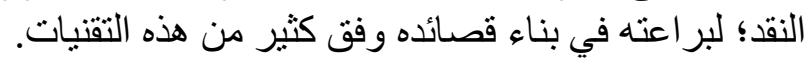




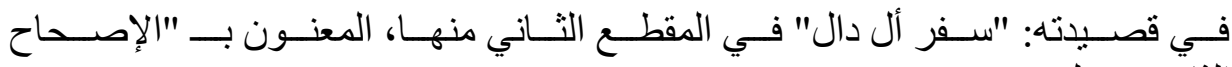

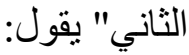

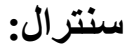
أعط للفتيات

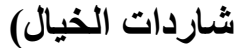

رقمي -رقم الموتـ حتى أجيء إلى العرس ذي الليلة الواحدة(')

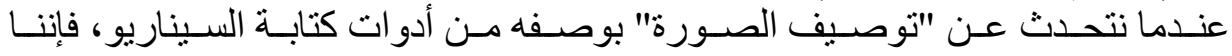

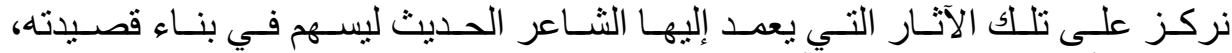

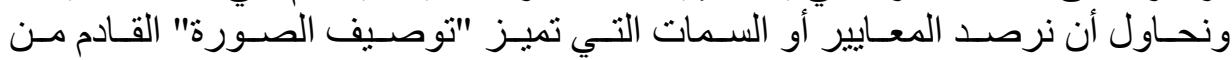

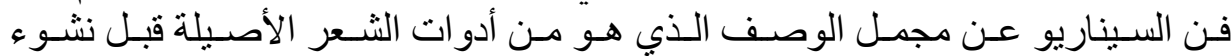
السينما والتصوير بالآلة عموما.

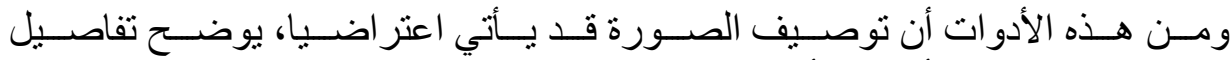
تصويرية ما لثخص أو كأن ائن أو مكان.

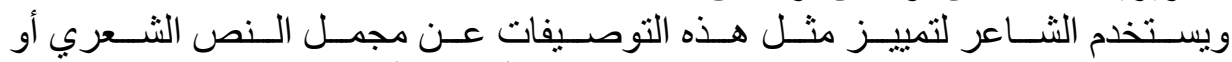

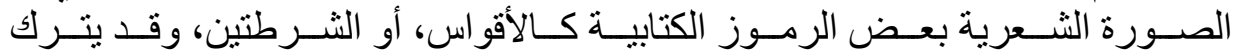

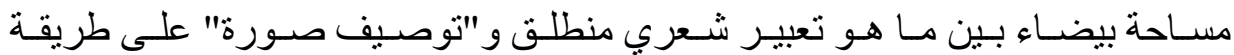
كتابة السيناريو. فتوصيف الصورة في النص السابق يتمثل في قول الثناعر: (اللواتي ينمن إلى جاتب الآلة الباردة البانئ

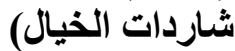

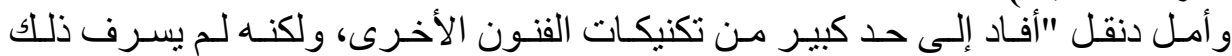

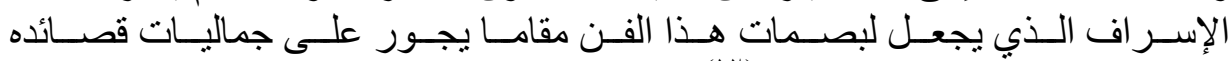

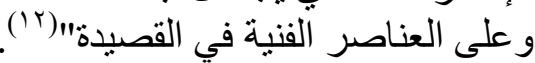

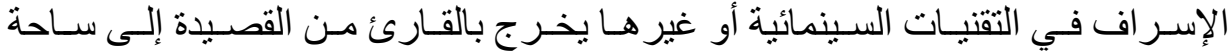

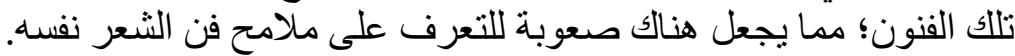

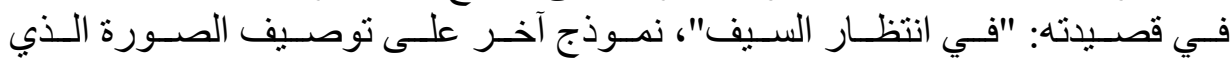
استخدم فيه الأقو اس لتمييزه عن بافي التفورة الصور الشعرية:

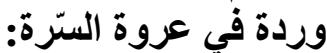
ماذا تلاين الآن ؟

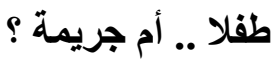
أم تنوحين على بوّابة القدس القديمةُ 
عادت الخيل من المشرق، عاد (الحسن الأعصم ) والمئ المثوت الموت المغير بالرداء الأرجواني، وبالوجه الأو اللصوصي، وبالسيف الأجير فانظري تمثاله الواقف في الميدان..

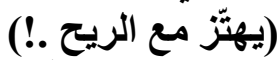
انظري من فرجة الثَبِّكاك:

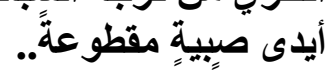

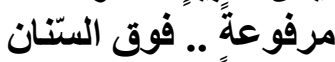

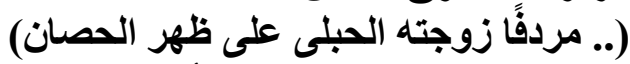

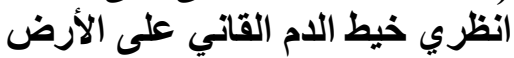

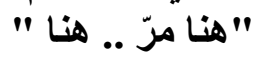
فانفقأت تحت خطى الجند . مناء ويون الماء،

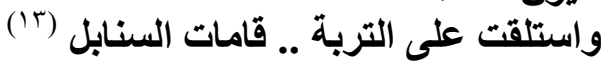

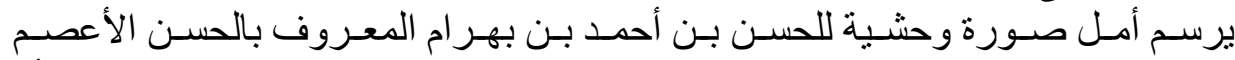

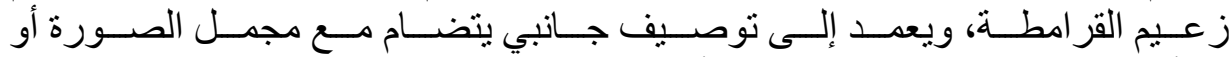

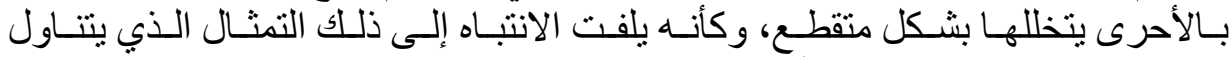

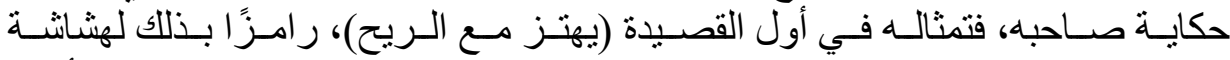

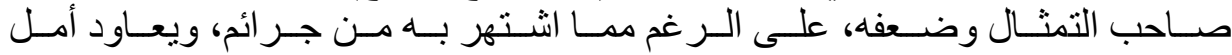

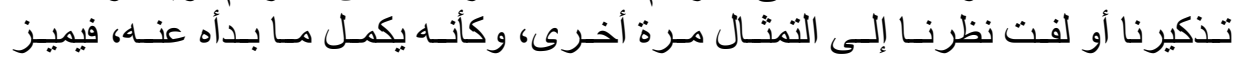

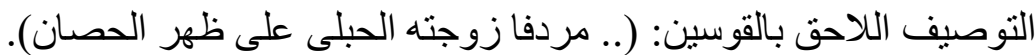

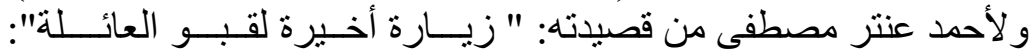
أيها الشبحُ المستحيل... قال لي حارس الليل: إنك كنت هنا؛ . . .

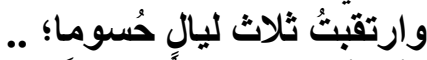

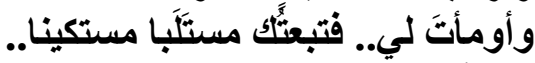

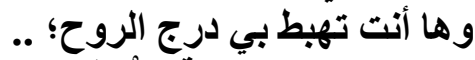

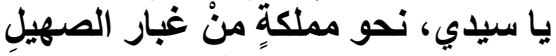

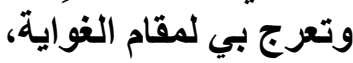

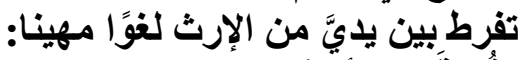

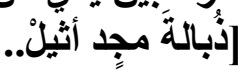


صورةً في إطار قديم لجدٍّ تمدد شاربهُ .. كالفتيلْ

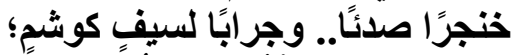

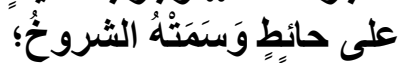

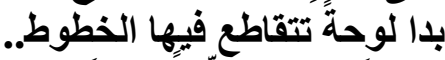

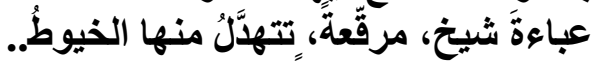

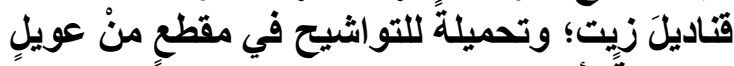
ومسبحة لأبي؛ حيثً كانت أصابعه حول حباتها تستدرُ السماوَ؛

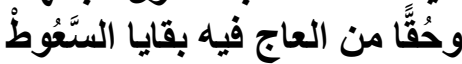

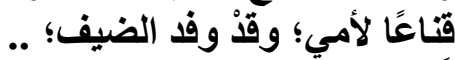

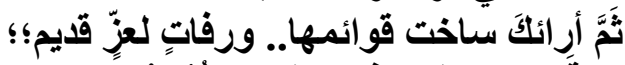

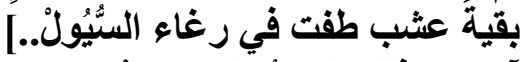
آه...، يا ذلك الثبحُ المستحيلْ أنت توجتني بالسرّرَ اب النبيل.. سنينا.. وفي وحشةُ القبو.. خلَفتنتي.. أعاني رطوبة هذا الفراغ المسمّر..

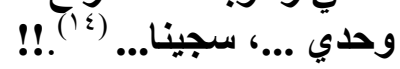

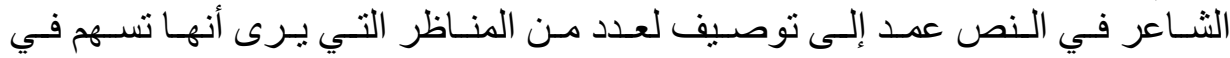

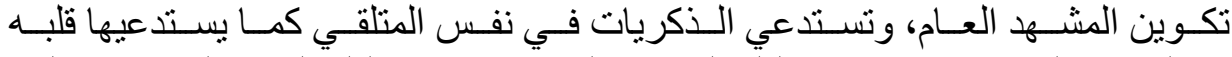

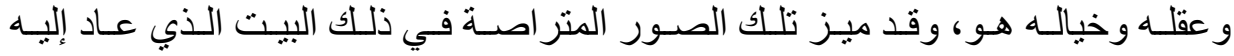

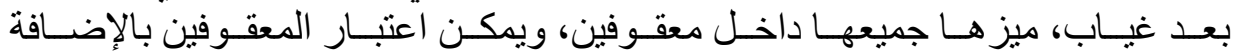

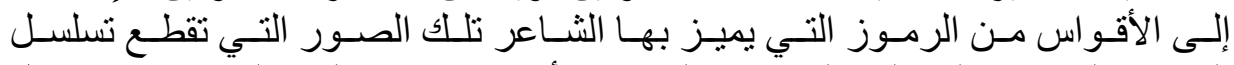

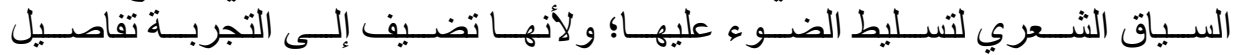

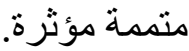

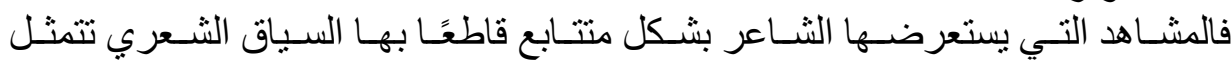

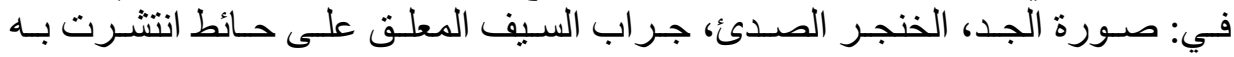

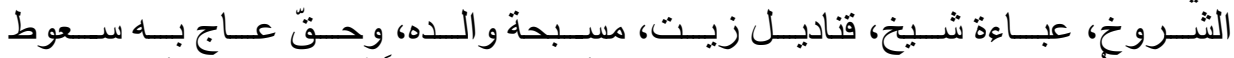

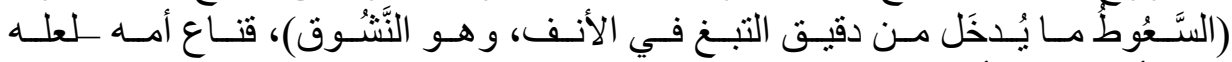
نقابها أو برقعها، أر ائك متهالكة.

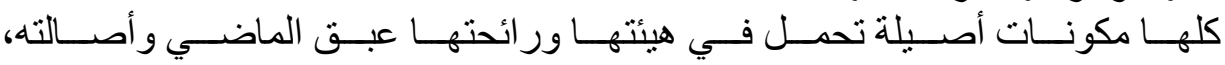

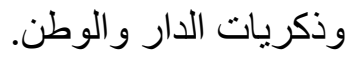




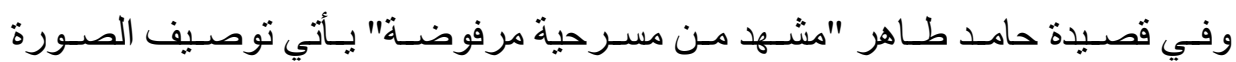

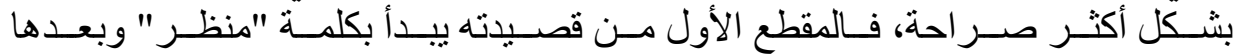

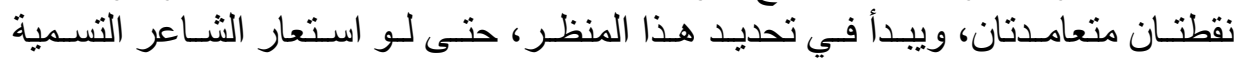

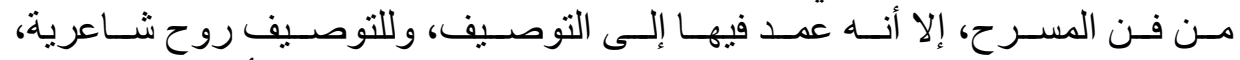

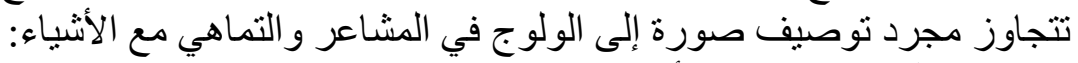
المنظر: "قيثارة .. تقلصت منه أوتار ها من الجليد

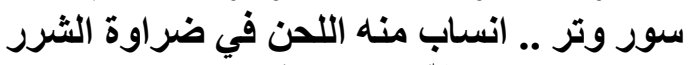

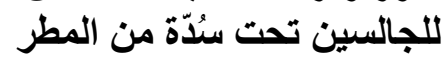

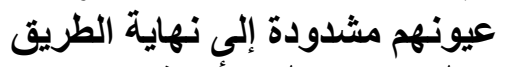

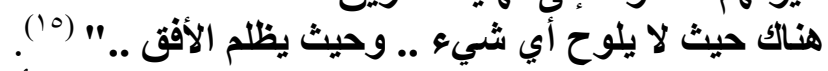

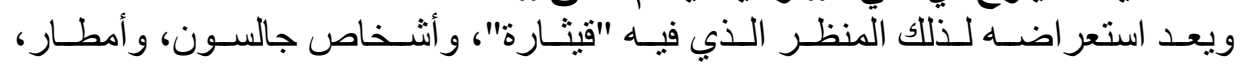

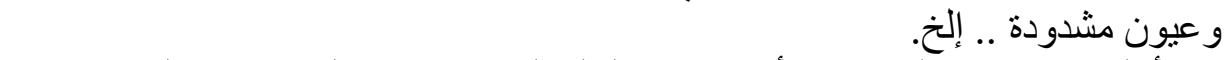

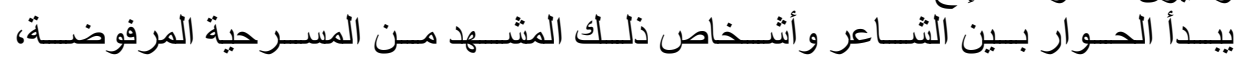
وسنتناوله في موضعان. توصيف الصوت

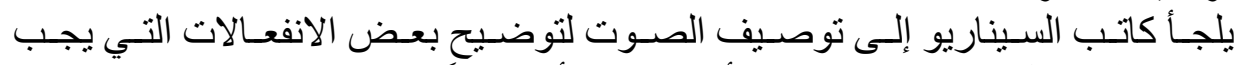

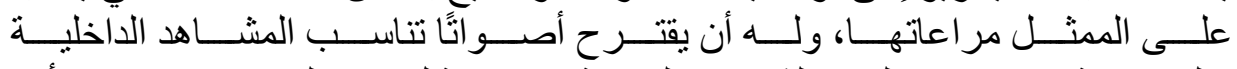

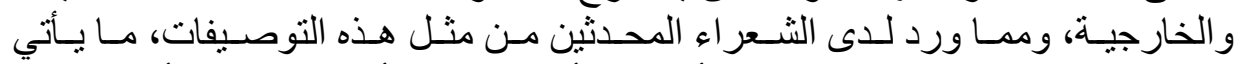

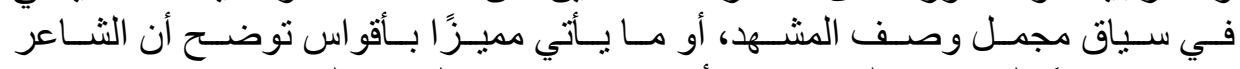

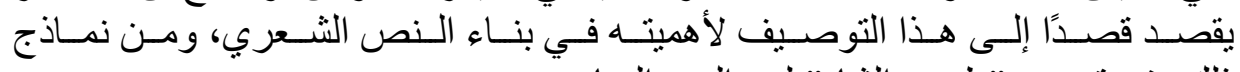
ذلك، في قصيدة "طريق الثام" لعز الدين المناصرة:

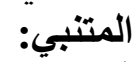
في باب الثين الثام قابلت المتببي وأبا تمام وذهبنا للحانة في الثط الثران الغربي المخمور (صاحبها ثرثار)

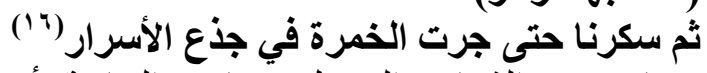

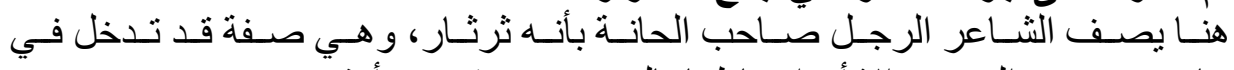

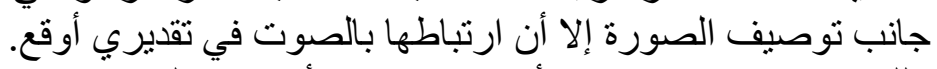

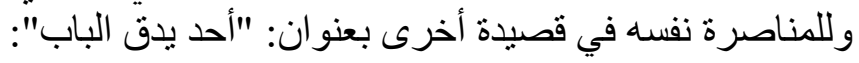
سبب خفيف ثم يتلوه انهمار مشاغلي فوق الغيوم 
سبب ثقيل هزني فرحتت في خوف التخوم

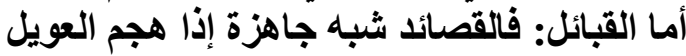
بعصيها وطبولها ثم الجرائد في المساء

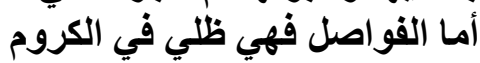

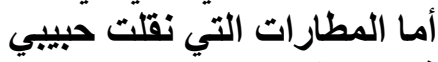

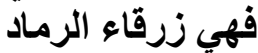
إن شُئت، أطفأت الجمار، رميتها في الريح فاندفق الحداد: (أحد يلق الباب هذي همهمات الريح تهمس للربيع

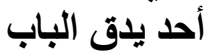
قاطعك القطيع.) الآخرون يُشرئرون ويطلبون المغفرة

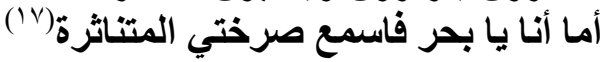

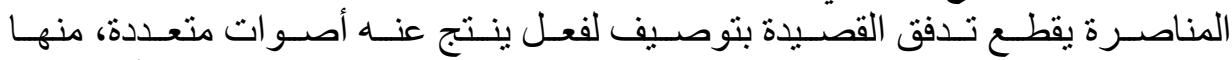

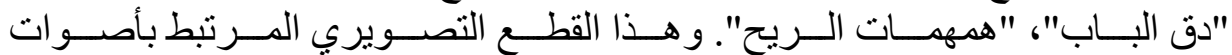

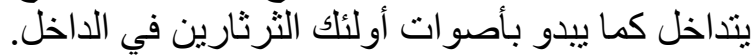

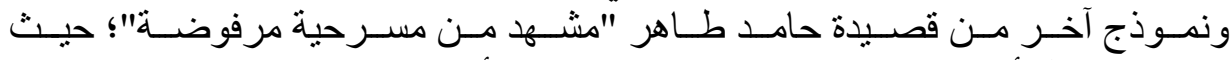
يصف رد فعل أولئك الذين كانوا يستمعون إليه عندما أخبر هم بما لا يسر: يا إخوتي معذرة إذاً فجأتكم بأسوأ الخبر را ربكم دفنته من ليلتين

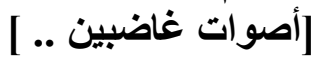

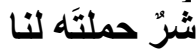
الثؤم في خطاك

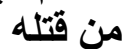

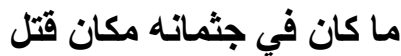

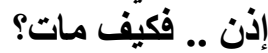
معذرة يا إخوتي إذا فجأتكم بأسوأ الخبر

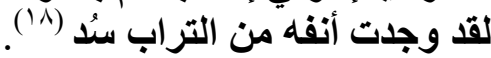




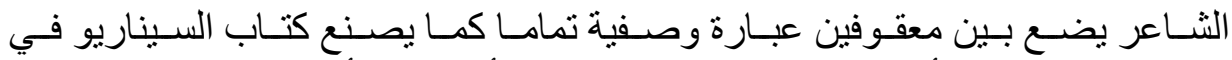

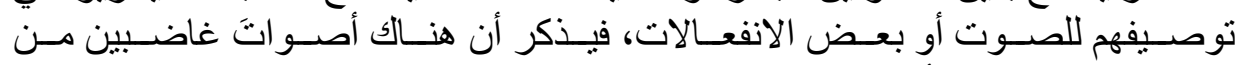

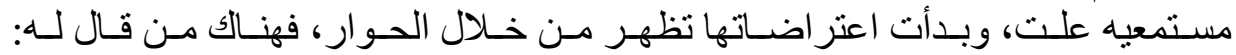

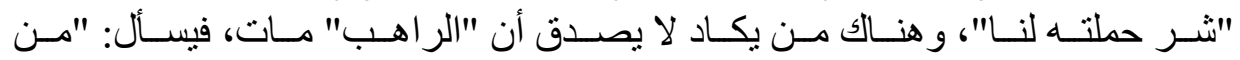

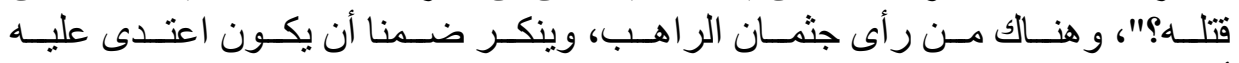

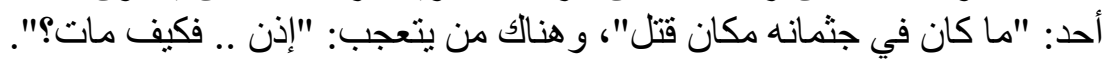

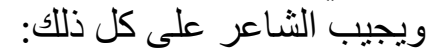
معذرة يا إخوتي إذا فجأتكم بأسوأ الخبر ذألفا

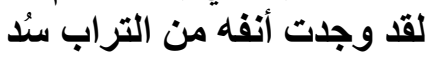

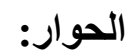

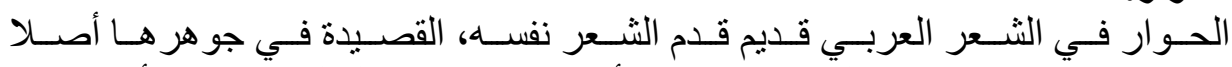

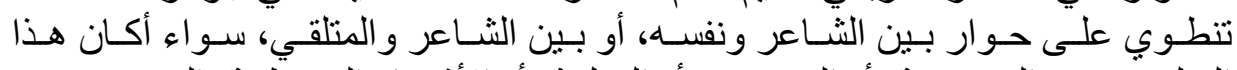

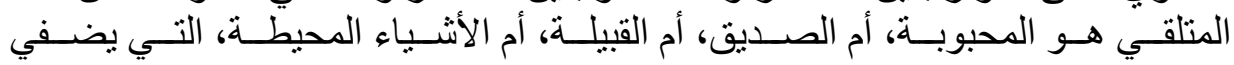
عليها المبدع سمات الحياة و التفاعل و المشاركة المبات الوجدانية.

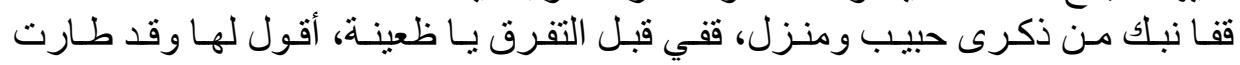

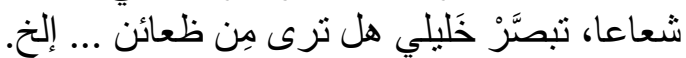

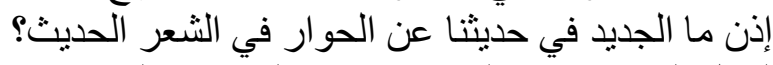

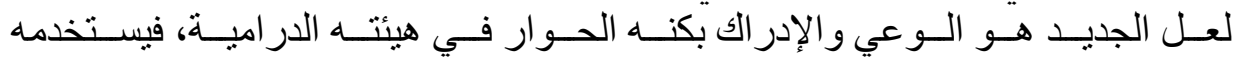

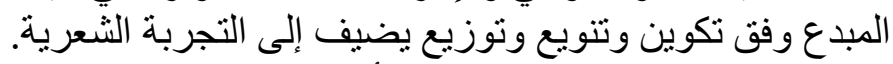

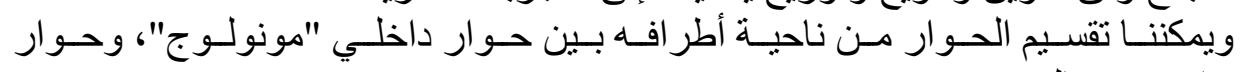

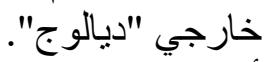

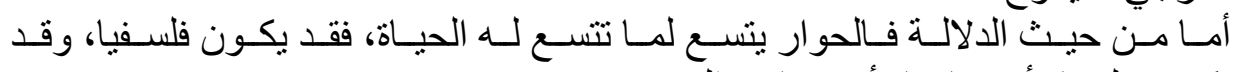
يكون تعليميا، أو سياسيا، أو دينيا ل... إلخ.

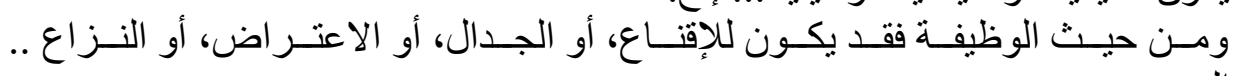
إلخ

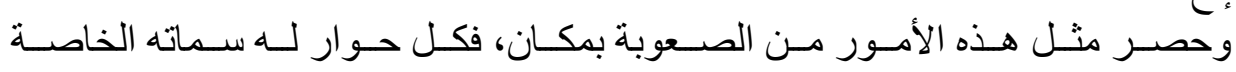
ووظبفته ودلالته في سياقه.

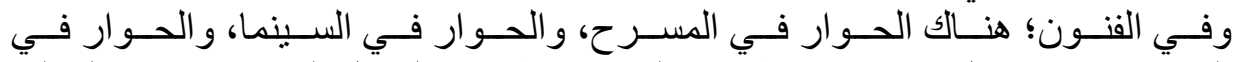

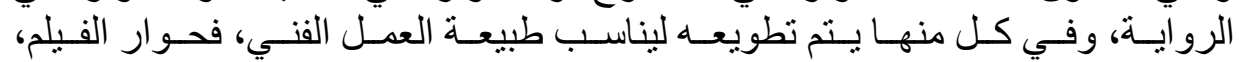

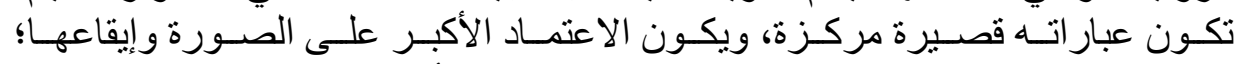

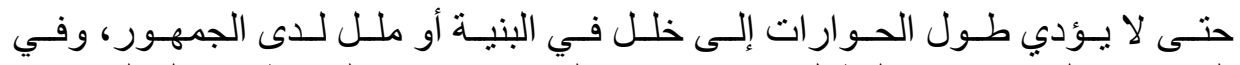

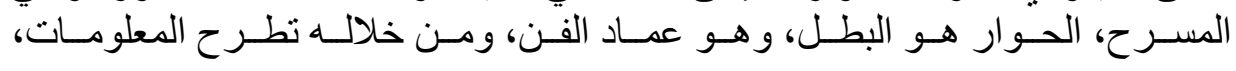




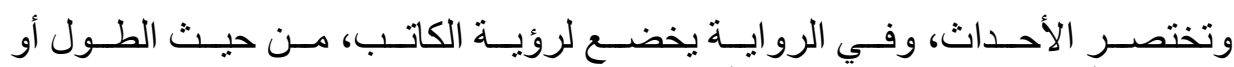

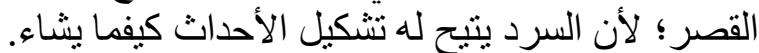

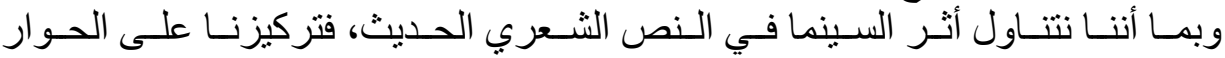

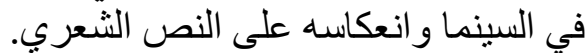

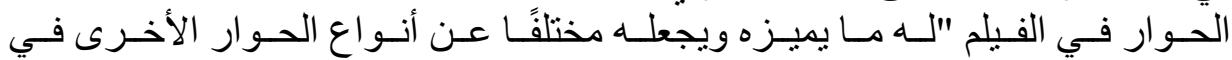

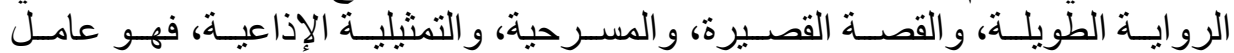

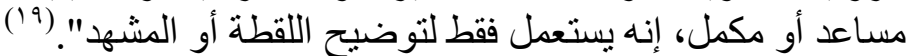

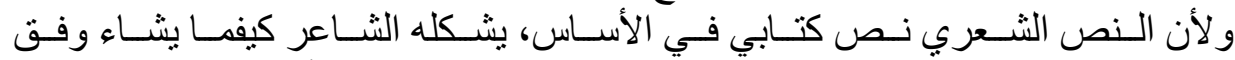

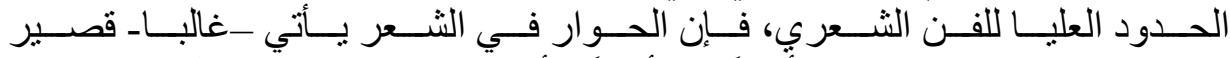

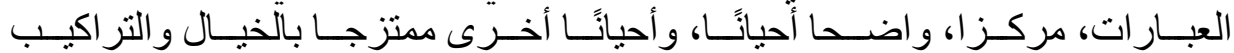

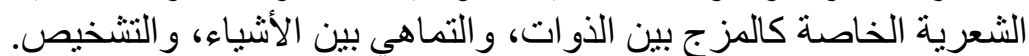

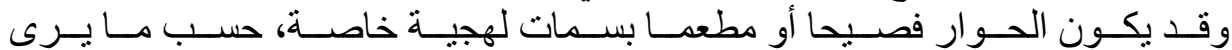

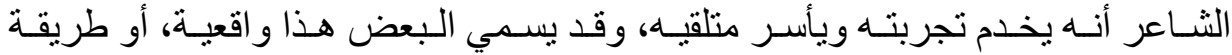

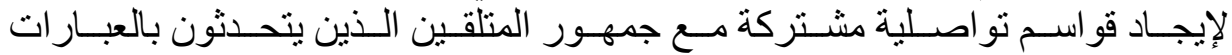

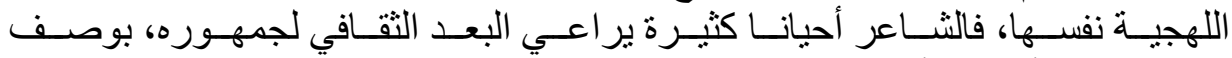
ذللك نو عا من أنواع الأصالة و الحنين إلى الوطن الوطن.

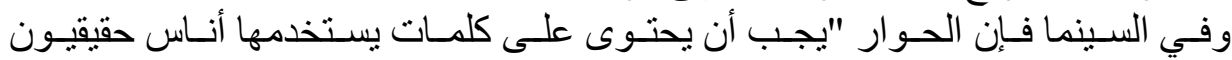

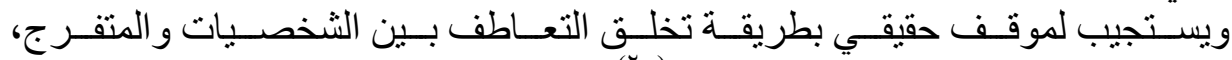

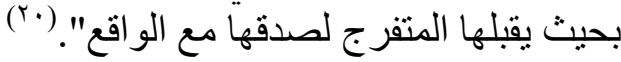
الحوار الخارجي

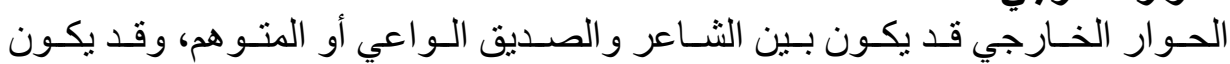

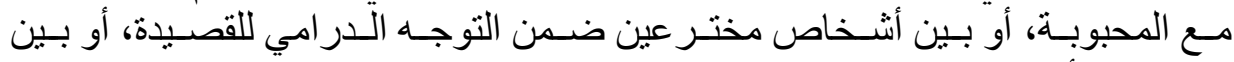

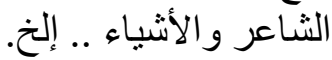

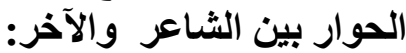

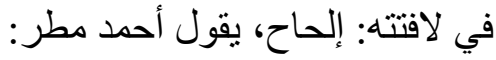

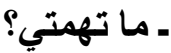
ـ تهمتك العروبة ـ قلت لكم ما تهمتي؟

ـ قلنا لك العروبة. ـ يا ناس قوليا لئوا غيرها. ـ أسألكم عن تهمتي.

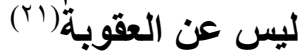




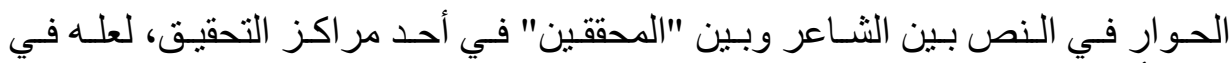

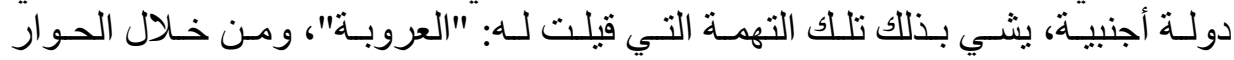

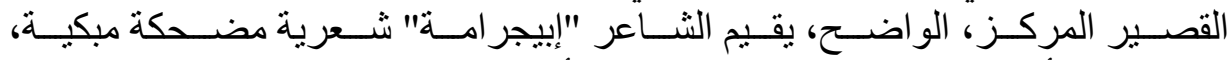

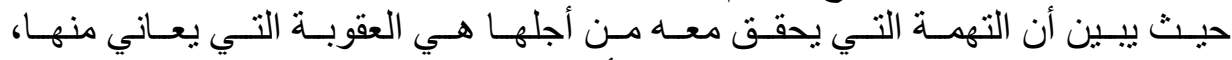

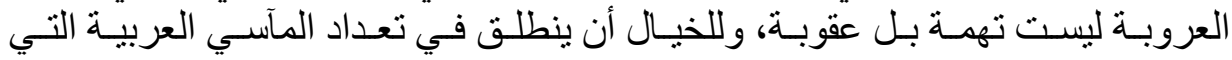
جعلت تللك الصفة عقوبة قاسبة.

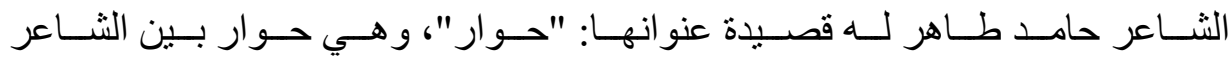
وصديقه:

عاصفة الليلة أقوى فلترجئ موعدنا للغد لا .. أعرف ركنا في هذاذ هذا المقهى حسنا .. ماذا تشرب؟ رينا في

اسمع

...

جيدة .. أدفأت الصدر تقسم من قلبي

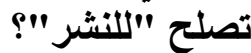
لا شيء بها غير "البيث الرابع" أحذفة

أصدق ما فيها سيضيع اللعنة .. ولماذا أكتب؟ مانب إنيع

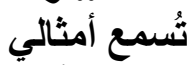

هل تعلم أنلك وحلك من يسمعني ..

فلتكرم "قارئك الأوحد" اطلب شايا وادفع هل تغضب! أبلا .. لكني منذ الآن سأكذب تغ 


\section{أصحبك لأقرب مقهى (Tr)

$$
\text { أصحبك لأقرب مقهى }
$$

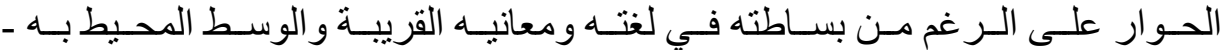

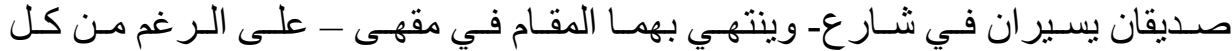

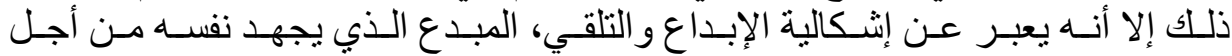

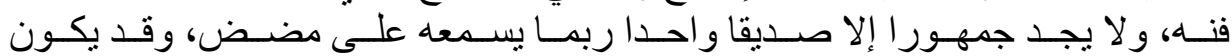

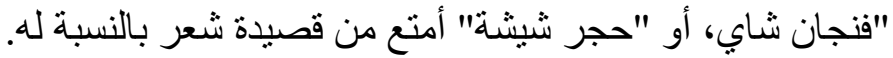

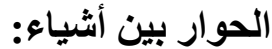

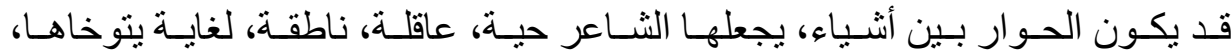

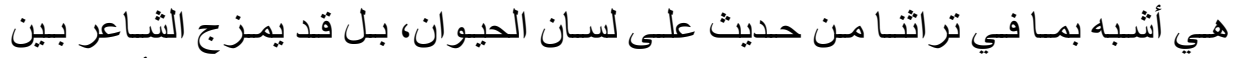

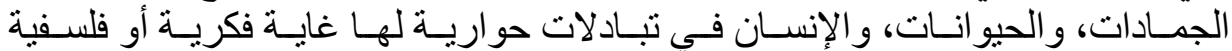

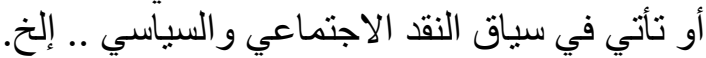

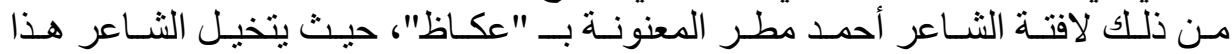
الحوار في سوق عكاظ، وهو السوق العربي القيم المشهور: الأرض: تُخري أنهر لكن قلبي نار.

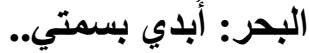
وأضمر الأخطار.

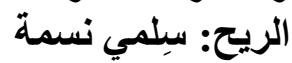
وغضبتي إعصار. الغيم: لي صي صواعق إعنى تمشي مع الأمطار. الصمت: في بالي أنا.. تزمجر الأقَكار.

الصخر: أدنى كرمي أن أمنح الأحجار لأشرف الثّوار.

النسر: رأيي مخلب ومنطقي منقار النمر: نابي دعوتي مخي . وحجتي الأظفار. الكلب: لست خائنًا ولست بـ بالغدار.

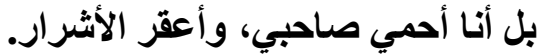
الجحش: نوبتي أنا بعد الأخ ألمنهار. العربي: ليس لي شيء سوى سوى الأعذار 


$$
\begin{aligned}
& \text { والنفي والإنكار } \\
& \text { والعجز والإلبار } \\
& \text { والابتهال، مرغمًا، للواحد القهار } \\
& \text { بأن يطيل عمر من يقصّر الأعمار؛ } \\
& \text { بالثكل إنسان أنا .. لكنتي حمار. } \\
& \text { الجحش: طارت نوبتي }
\end{aligned}
$$

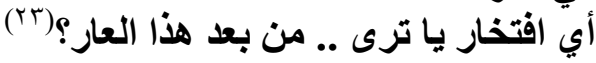

$$
\begin{aligned}
& \text { وفخر قومي طار. }
\end{aligned}
$$

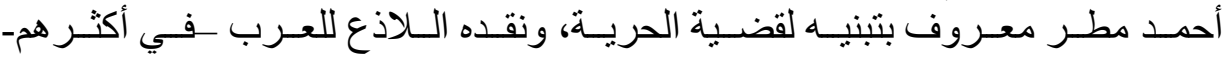

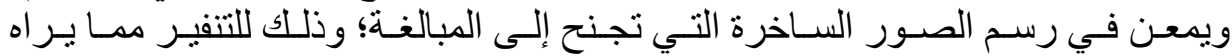

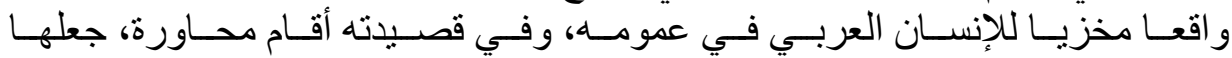

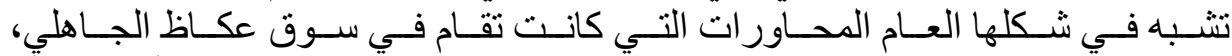

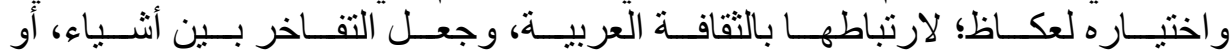

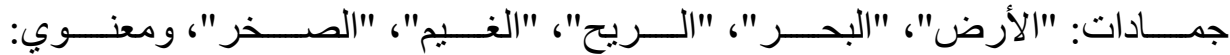

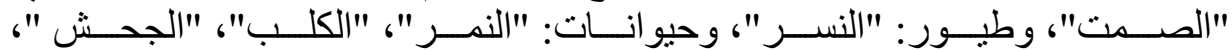

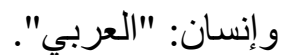

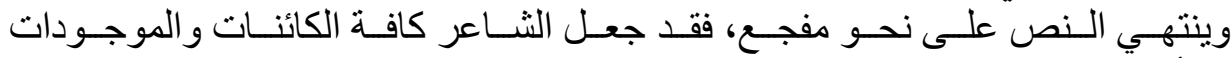

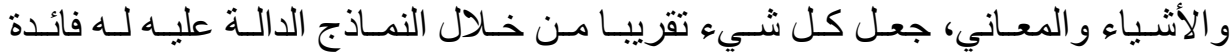

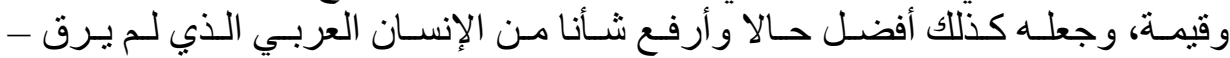

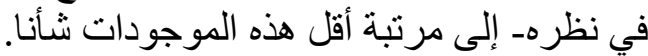

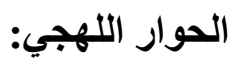

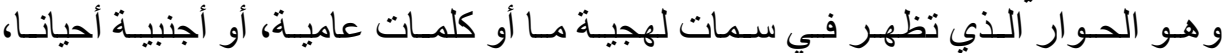

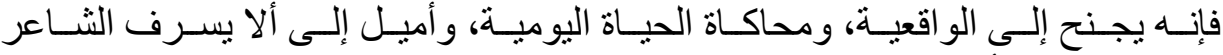

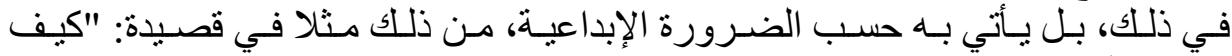

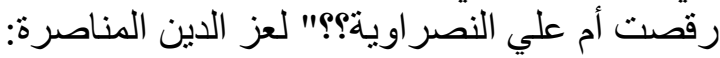

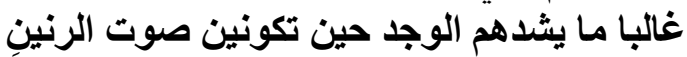

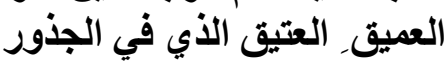
رجع صوتك مثل نبيذ الأغاني العتيقة مثل نبيذ التئل التلال

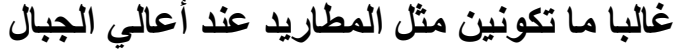

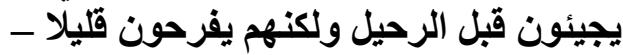

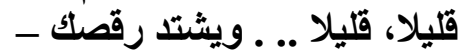


لا تفتحي الجرح أو تغلقيه.

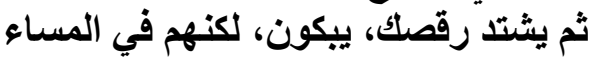

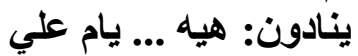

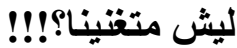

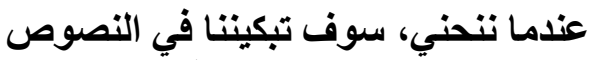

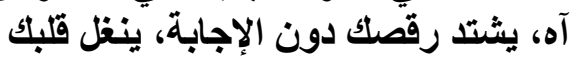
بين مروج الكلام

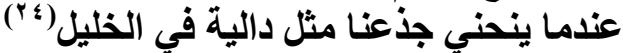

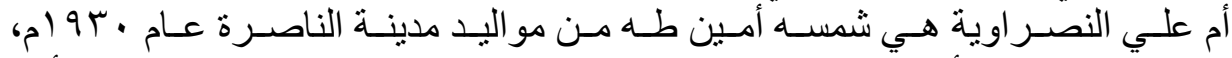

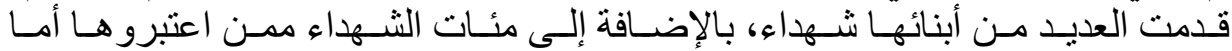

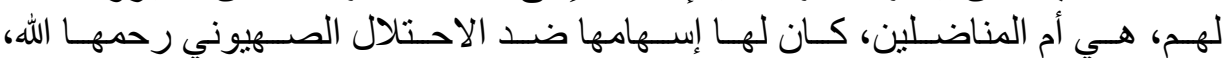
وقد كرمها الرئيس عرفات المناض رحمه الله.

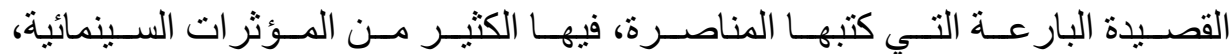
ومما ييرز فيها من مقاطع الحوار العامية الفلسطينية: ثم يشتد رقصك، يبكون، لكنهم في المساء

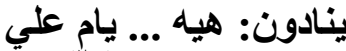

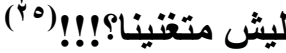

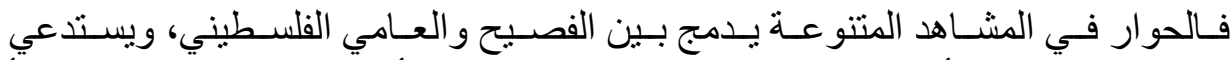

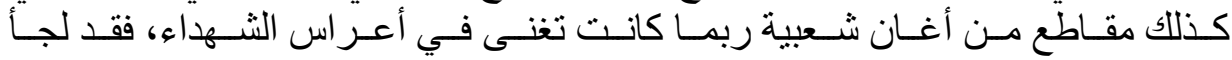

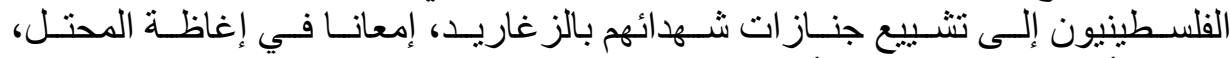

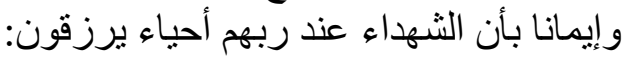
سوف تبكينتا بالكلام الجليل

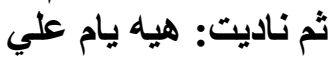

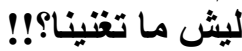

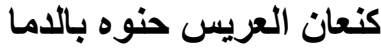

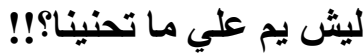
آه، يشتد رقصك -إن حذاعك مهترئ وقطظتّ في مسارب هذا الرحيل

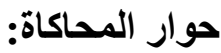




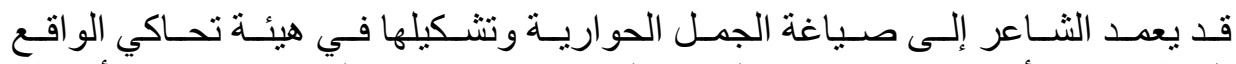

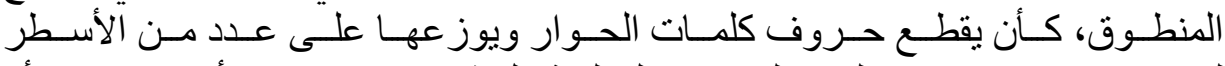

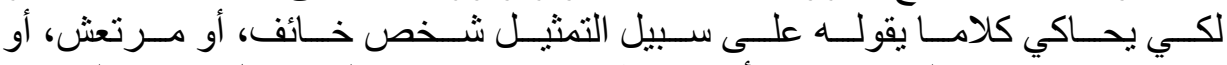

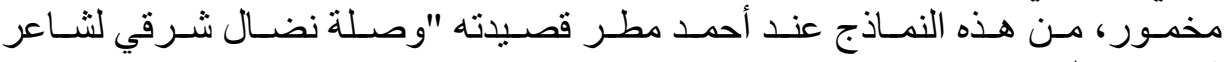

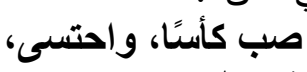

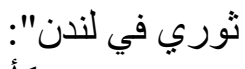

جفنه انشد إلى الأعلى ببطءٍ ثم مطق. وانزلق إلى الأقل

$$
\text { وتز وتمطى شتى }
$$

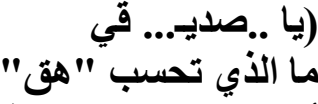

أوْصلنا، اليوم، إلى هذا النقق؟ "هى" )

واحتسى ونسي

$$
\text { ثم مطق: }
$$

(هق .. .. هو الغقلة والنوم ولن نخرج إن.. لم ... نستفق.

من هنا .. "هن هن انق من هنا سوف يكون الـ .. منطلق) وتمطى وبصث لون لـون وتراخى فارتخت راحته فوق الورق

وتغطى بغطيط

واختنق!

قد صدق من هنا سوف يكون المنطلق 


\section{إيسبح منا شعراء في النضالات

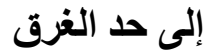 ويذويون كفاحًا

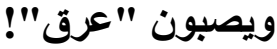 \\ وينامون لكي تستيقظي

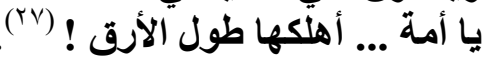

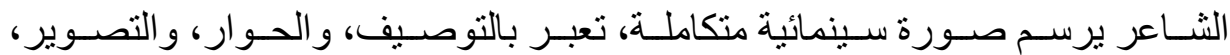
و والمونتاج، والصوت ومؤثر اته كذلك.

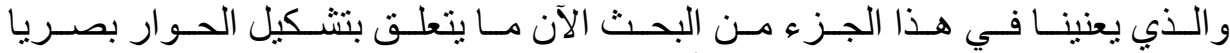

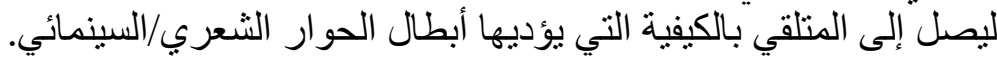

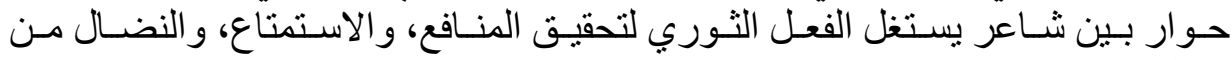

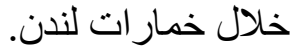

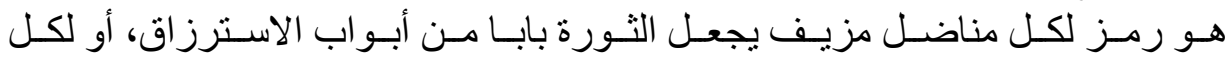

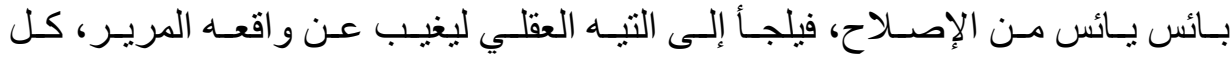

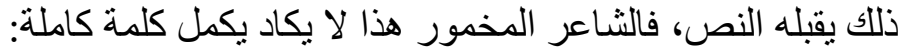

$$
\begin{aligned}
& \text { (هق .. .. هو الغفلة والنوم النقام } \\
& \text { ولن نخرج إن.. لم ... نستفق. } \\
& \text { من هنا .. "هق انق" } \\
& \text { من هنا }
\end{aligned}
$$

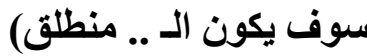

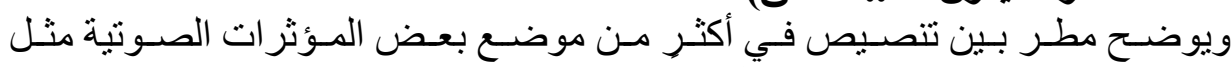

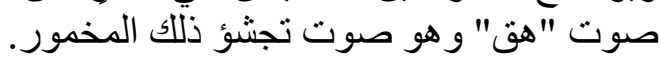

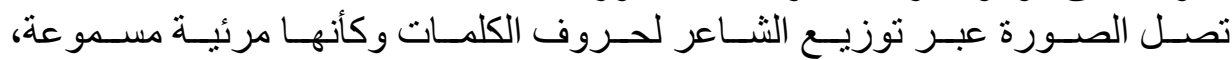

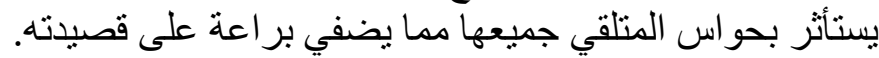

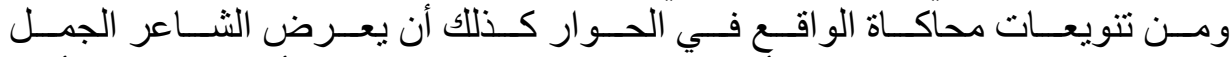

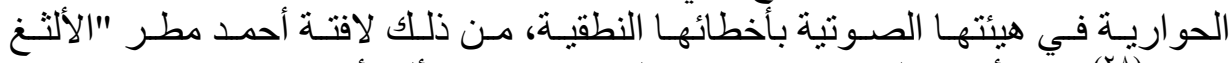
بحتج"(م^) حيث أورد كلمة "و غد" وفسر الثشاعر مقصد الألثغ أنها "ورد".

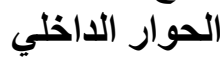

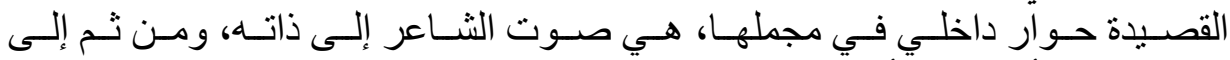

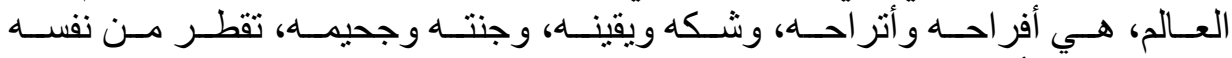
وترتثفها مرة أخرى، ويكون المتلقي تاليًا. 


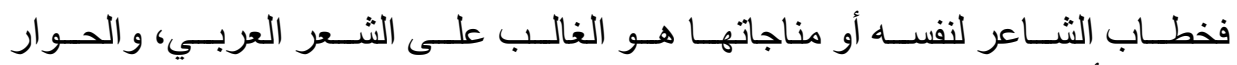

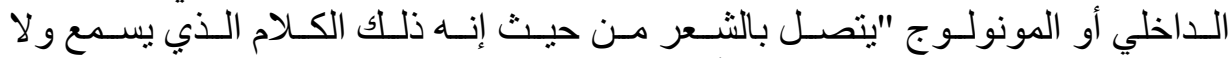

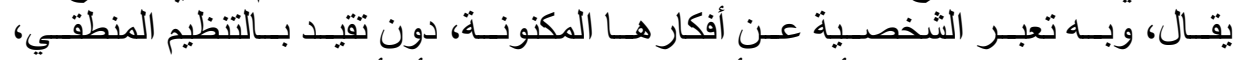

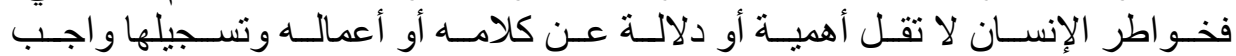

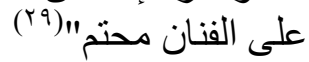

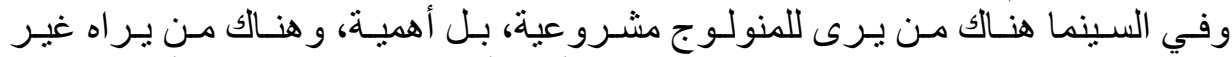

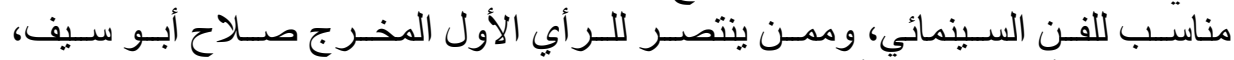

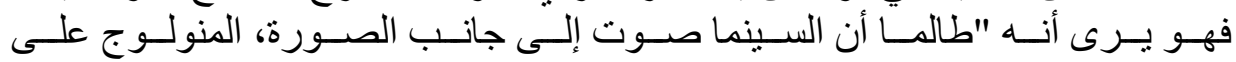

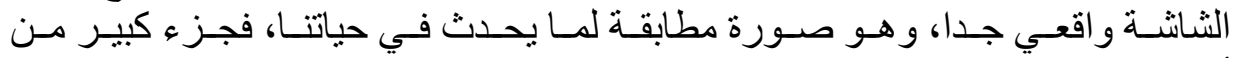

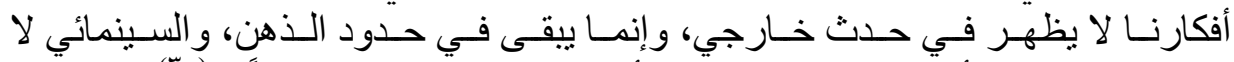

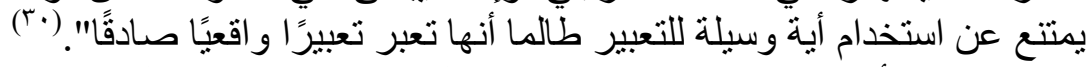

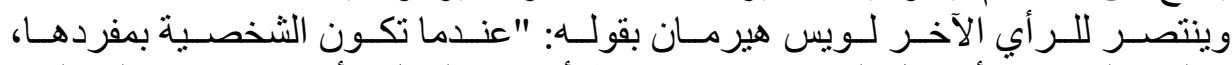

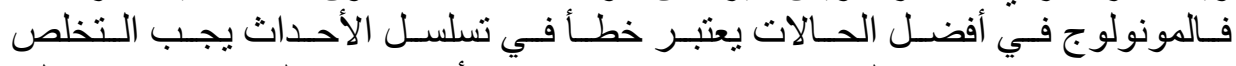

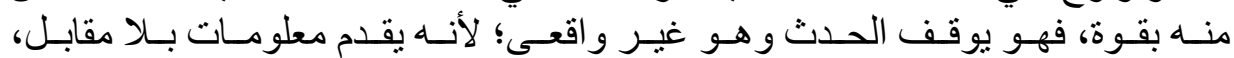

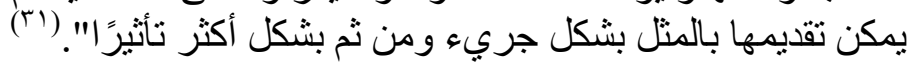

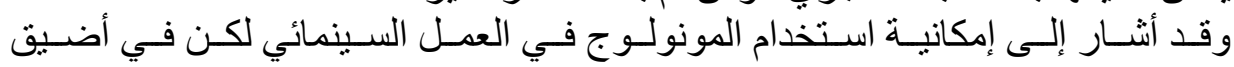

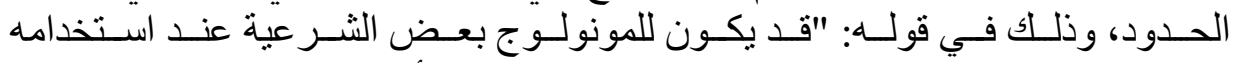

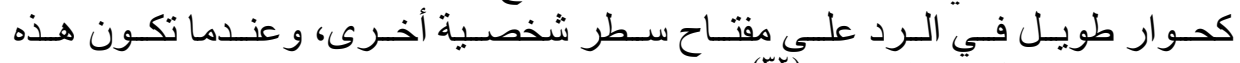

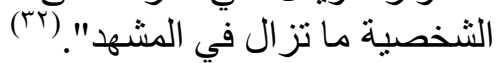

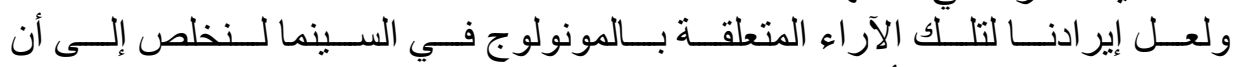

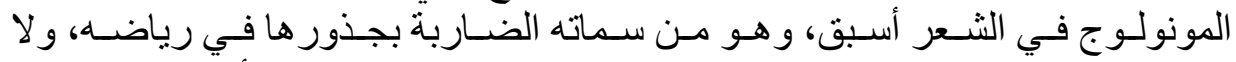

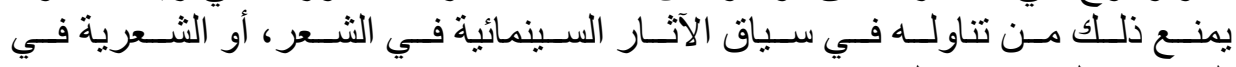

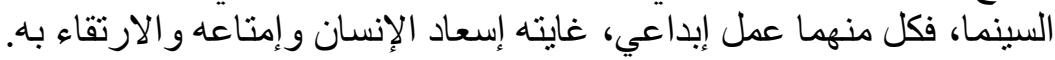

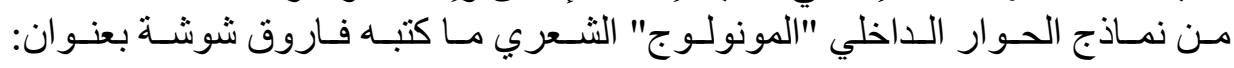
"رؤيا":

رأيت الذي لائي يراه سواي

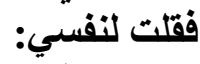
لو اني نطقت بما أسعدتني به الحال

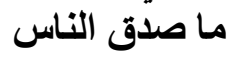
وارتاب أكثر هم في يقيني وظني وقالوا: لله الله يهذي بما ليس يلهري 
ويبصر ما لا يرى

ويضل ضلالا بعيدا

له الله!

فعلا لي الله

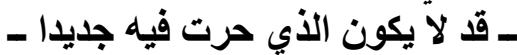
وماذا أرجي من اللغافلين وهم في عمايتهم بين بين الغرانين فآنا يرون، وآونة ل آلا يرون؛

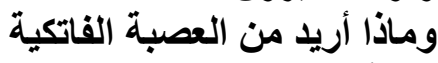
وقد أمسكوا برقاب العن العباد ولكنهم في ختام المطاف حثالة هذا البشر! وماذا إذا بحت بالسر؟ هل يقتلوني؟ منذ قديم يباح دم العاثقين إنين ـ إذا نطقوا أو أشاروا وهل يطلقون لساني قسرا فلا أتوقف بطف حتي يروا قاع نفسي ومكنون ذاكرتي ونفائس مقتنياتي وغيبي وصحوي وحتي أرى عاريا قد خرجت كما قد ولات آلات بلا شملة أو دثثار ـ لماذا يريدونتا هكذا دائما

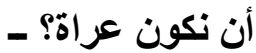
وساعتها يطمئنون لي في لئون ثم يفسح شيخهمو لي مكانا لعلي أجالسهم وأقول الذي لـي لم أقله

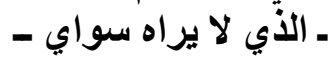




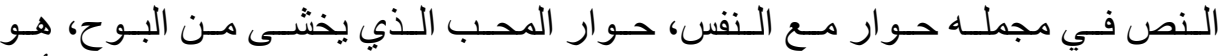

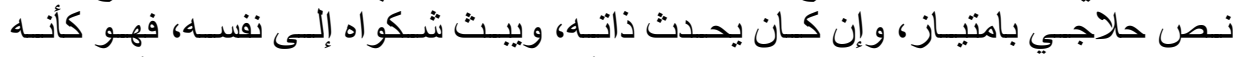

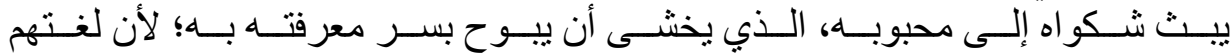

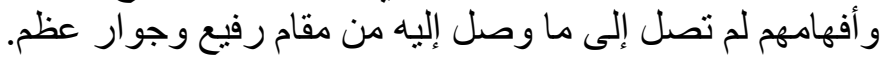

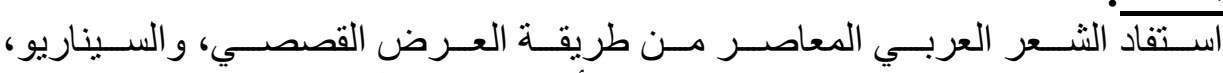

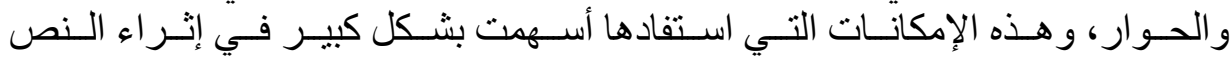

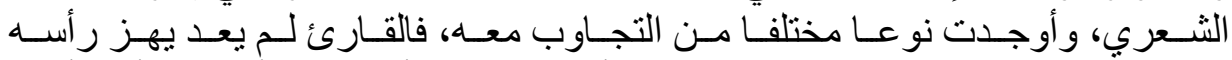

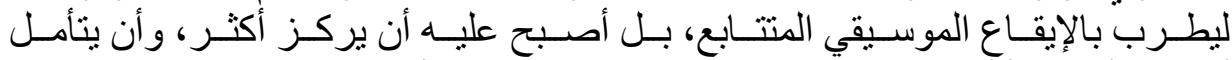

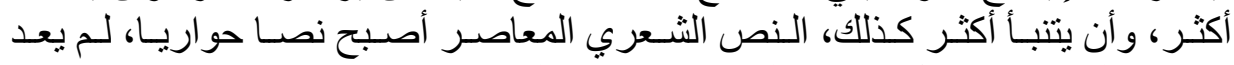

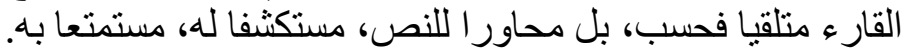

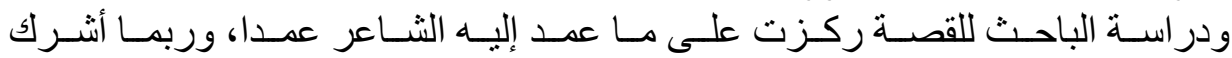

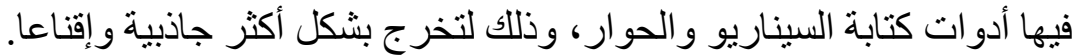

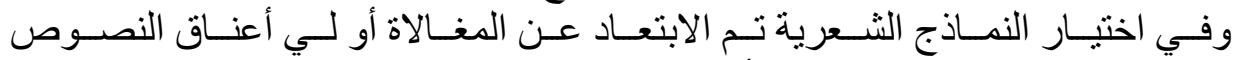

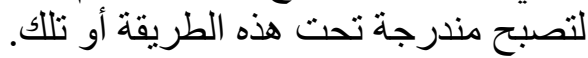

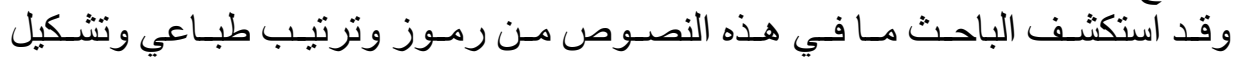

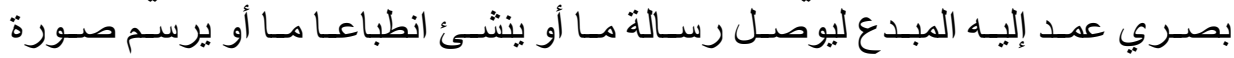

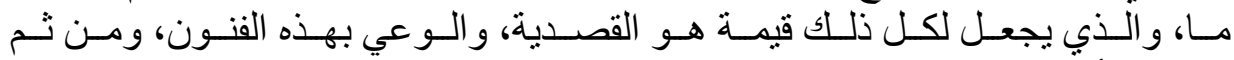
إحداث الأثر في المتلقي.

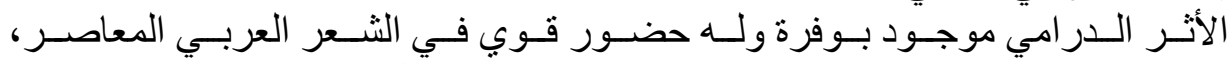

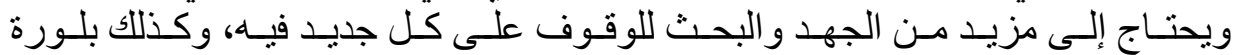
أكثر وتطبيقا أعمق؛ فهو يستحن ذلك الكه عن جدارة. 


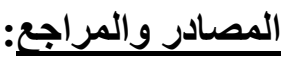

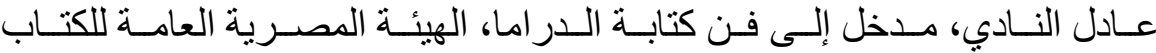

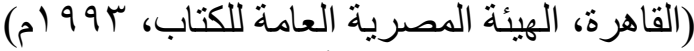

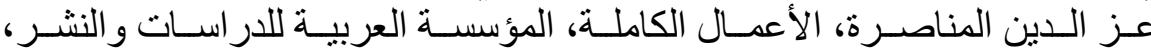

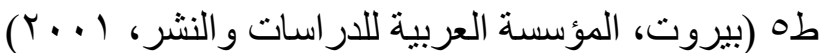

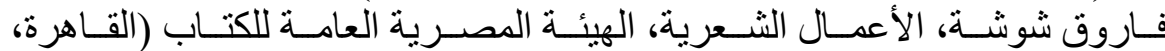

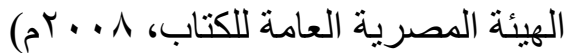

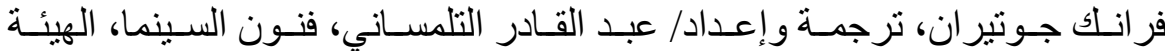

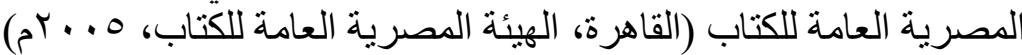

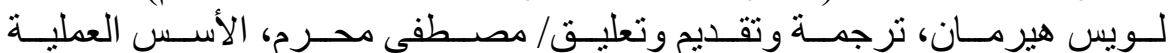

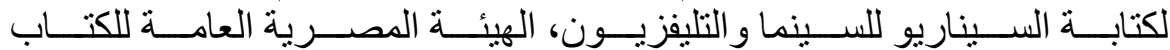

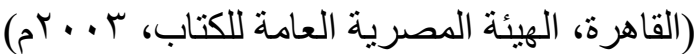

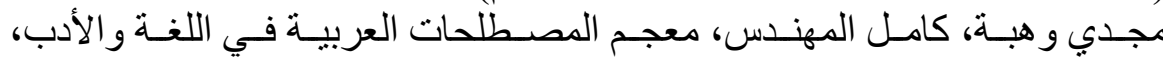

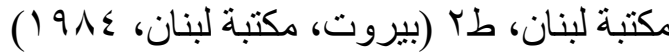

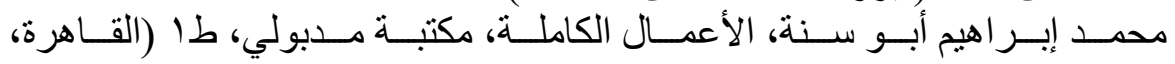

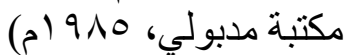

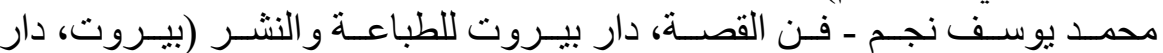

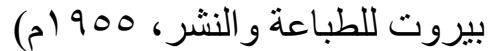

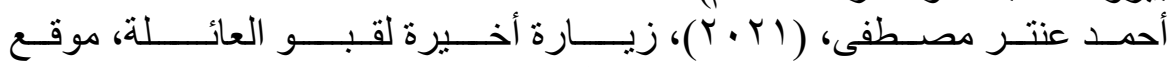

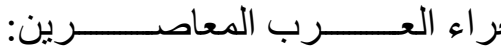
(- مابطين للثن الب https://www.almoajam.org/Encyclopedia/poet/0135.htm 
(') معجم المصطلحات العربية في اللغة والأدب - مجدي و هبة، كامل المهندس - طب (مكتبة

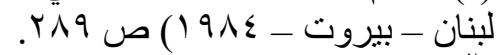

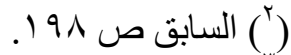

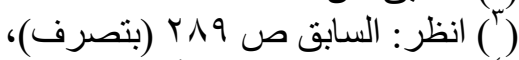

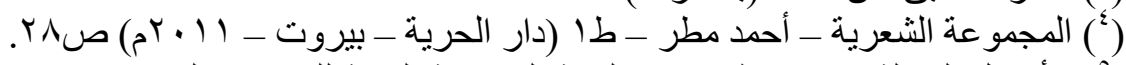

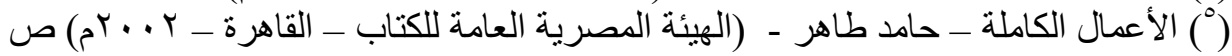
rON_rOV (ج) انظر : معجم المصطلحات الأدبية - إبر اهيم فتحي - (المؤسسة العربية للناشرين المتحدين

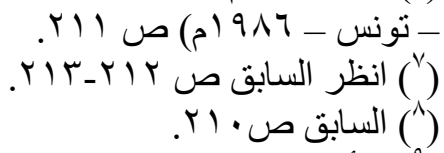
(9) الأعمال الكاملة - محمد إبراهيم أبو سنة - طا (مكتبة مدبولي - القاهرة - 910 (م) صن (') فنون السينما - فرانك جوتيران - ترجمة و إعداد/ عبد القادر التلمسانى (الهيئة المصرية

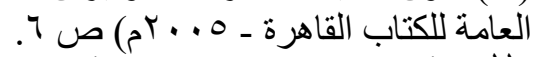

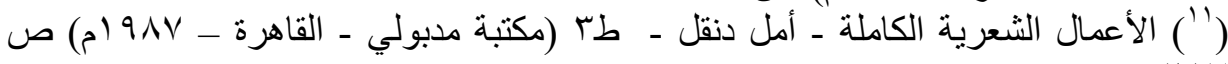

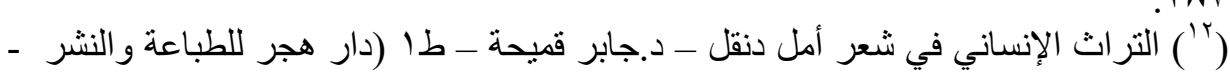

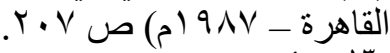
إل

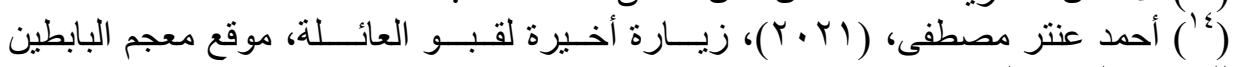
للشعر اء العرب المعاصرين: https://www.almoajam.org/Encyclopedia/poet/0135.htm (10)

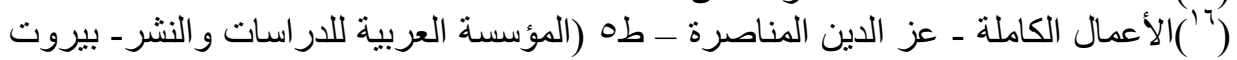

$$
\text { (r) }
$$

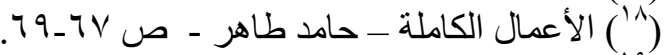

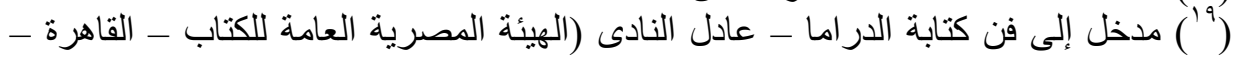

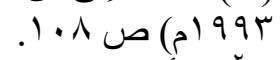

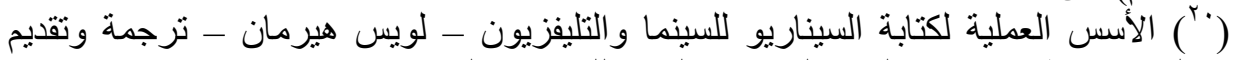

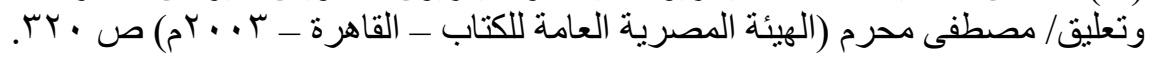




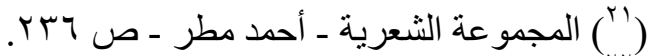

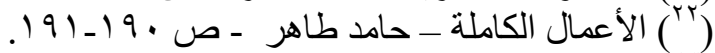

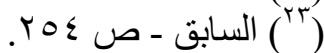

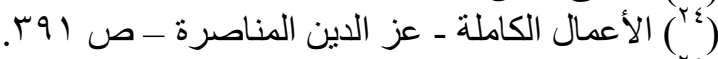

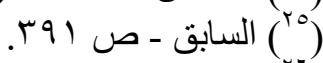

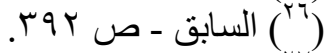

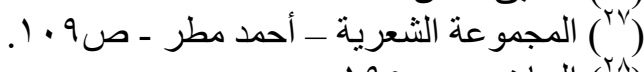

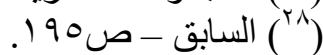

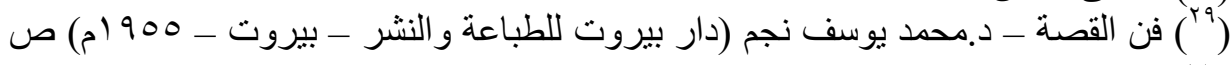
(·•) السيناريو والسيناريست فى السينما المصرية - سمير الجمل (الهيئة المصرية العامة

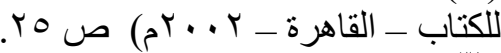

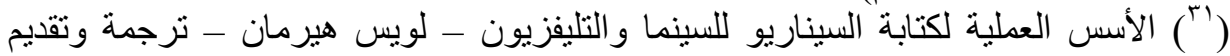

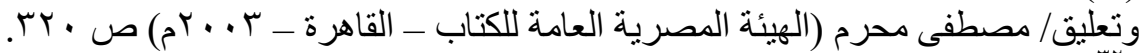

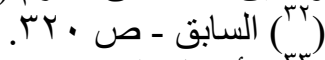

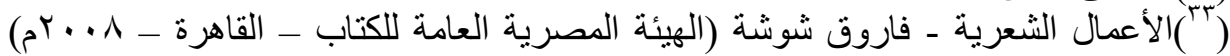

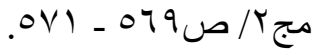


د.عبل اللها رمضان خلفـ مرسي

القصة والسيناريو والحوار في النص. 